\title{
The Holding Company Discount in Korea's Stock Market
}

\author{
Jin Park, Ph.D. Student, Sungkyunkwan University \\ Jungwon Suh", Professor, Sungkyunkwan University \\ Shinwoo Kang, Assistant Professor, Sejong University
}

\begin{abstract}
$\langle$ Abstract $\rangle$
This study finds that holding companies (i.e., those that are founded pursuant to Korea's Monopoly Regulation and Fair Trade Act) are traded at lower values than are other companies in the stock market. Our investigation of listed firms over the period 2002 2017 reveals that the mean and median market-to-book equity ratios of holding companies are significantly below 1 and substantially lower than those of other companies. This valuation discount remains significant even when comparing holding companies with their subsidiaries and in multiple regressions that control for various firm characteristics and business-group fixed effects. Furthermore, holding companies' values are significantly lower than their fundamental values as estimated using Campello and Graham's (2013) method. In comparison, de facto holding companies, which are defined as operating firms that serve as holding companies for business groups, do not display a valuation discount. Our results show that the holding company discount is related to investors' tendency to shun holding companies, as indicated by the relatively small turnover of holding companies' stocks. Additionally, the holding company discount may arise partly because most holding companies are listed together with their operating subsidiaries, and investors concentrate their demand on (pure-play) operatingsubsidiary stocks, rather than on holding-company stocks. It appears that the holding company discount is a phenomenon unique to Korea, as similar discounts are not found in the stock markets of Japan or the United States.
\end{abstract}

Keywords: Holding Company; Business Group; Firm Value; Discount; Investor Demand JEL Classification: G14, G30

* This work was supported by the Ministry of Education of the Republic of Korea and the National Research Foundation of Korea(NRF-2017S1A5A2A01023991).

** Corresponding Author. Address: Business School, Sungkyunkwan University, 25-2 Sungkyunkwan-ro, Jongno-gu, Seoul, Korea 03063; E-mail: jungwonsuh@skku.edu; Tel: +82-2-760-0482; Fax: +82-2-760-0440.

Received: July 11, 2019; Revised: August 31, 2019; Accepted: September 5, 2019 


\title{
한국주식시장의 지주회사 디스카운트
}

\author{
박 진 (성균관대학교 박사과정) \\ 서 정 원 (성균관대학교 교수)** \\ 강 신 우(세종대학교 조교수)
}

본 연구는 2002 2017년 기간의 비금융 상장기업을 대상으로 공정거래법에 따라 설립된 지주회사(이하 지주회사)가 다른 기업(이하 비지주회사)에 비해 기업가치가 저평가 되어 있는지 분석하고 그 원인을 탐구하였다. 분석 결과 지주회사의 자기자본 시장가치-장부가치 비율(M/B equity)의 평균은 0.654 로 1 에 훨씬 못 미치며, 비지주회사에 비해 유의적으로 낮은 디스카운트 현상이 존재함을 발견하였다. 이 디스카운트는 기업집단 내의 자·손자회사와 비교해도 유의하며, 기업가치에 영향을 미치는 변수들을 통제한 다변량 회귀식에서도 유의하였다. 또한 Campello and Graham(2013)의 방법론을 사용한 결과 지주회사는 기업펀더멘탈에 비해서도 낮은 기업가치를 나타내었다. 한편 사실상의 지주회사(공정거래법상 지주회사는 아니지만 기업집단의 지주회사 역할을 하는 사업회사)의 기업가치는 저평가되어 있지 않았으며, 따라서 지주회사 디스카운트는 공정거래법상 지주회사에 대해서만 나타나는 현상임을 알 수 있었다. 지주회사 디스카운트의 원인을 명확히 밝히기는 힘들지만, 지주회사 주식의 거래회전율이 타 주식에 비해 상당히 낮고 지주회사 전환 후에 급격히 하락하는 것으로 보아 투자자들은 고유사업이 없고 자회사 통제관리를 목적으로 하는 지주회사를 매력적인 투자대상으로 생각하지 않는 것으로 추측된다. 또한 대부분의 지주회사는 사업자회사가 함께 상장 되어 있는데, 투자자들은 지주회사보다는 사업자회사 쪽으로 투자수요를 집중하여 지주회사 디스카운트가 발생하거나 심화되는 것으로 추측된다. 일본의 지주회사에게는 디스카운트 현상이 없는 것으로 보이며, 지주회사 디스카운트는 한국시장 특유의 현상인 것으로 보인다.

핵심 단어 : 지주회사, 기업가치, 디스카운트, 비즈니스그룹, 기업집단

JEL 분류기호: G14, G30

* 이 논문은 2017년 대한민국 교육부와 한국연구재단의 지원을 받아 수행된 연구임(NRF-2017S1A 5A2A01023991).

** 연락담당 저자. 주소: 서울특별시 종로구 성균관로 25-2 성균관대학교 경영대학, 03063;

E-mail: jungwonsuh@skku.edu; Tel: 02-760-0482; Fax: 02-760-0440. 


\section{1. 서론}

공정거래법에서 지주회사(Holding Company)는 '주식의 소유를 통하여 다른 회사의 사업 내용을 지배하는 것을 주된 사업으로 하는 회사'로 정의되며 구체적으로는 '대차대조표상 자산총액이 5,000억 원 이상이며 소유하고 있는 자회사의 주식가액의 합계액이 자산총액의 $50 \%$ 이상인 회사'로 규정된다. 1 공정거래위원회 자료에 의하면 2018년 9월 현재 지주회사의 수는 모두 193 개(금융지주회사 10 개 포함)이다. 1999년 지주회사의 설립이 허용된 후 지주회사의 수는 꾸준히 증가해 왔으나 지주회사에 대한 기업재무 분야의 연구는 다소 저조한 편이다.

본 연구의 주제는 지주회사의 기업가치가 타 회사에 비해 저평가 되어 있는가 여부이다. 지주회사의 기업가치가 타 기업에 비해 저평가 되어 있다는 인식은 한국시장의 참가자들에게 널리 퍼져 있고 저평가를 시사하는 일화성 증거가 신문과 블로그 등에서 자주 언급되고 있다. 하지만 이 주제에 대한 학술논문은 부재한 실정이다. 본 논문은 비금융 상장회사 전체를 연구표본으로 하여 지주회사 기업가치의 저평가 문제에 대해 종합적인 분석을 실시하고자 한다. 한편 공정거래법상 지주회사는 한국 특유의 회사 형태이기 때문에 미국의 선행연구 중에는 지주회사의 기업가치에 대한 연구가 없다. 일본에서는 순수지주회사의 설립이 2000년대부터 꾸준히 증가하였으나 일본의 선행연구 중에서도 지주회사의 기업가치에 대한 연구가 학술지 게재논문 중에는 없다. ${ }^{2}$

분석을 위해 2002 2017년의 기간을 대상으로 상장회사 중 공정거래법상 지주회사 68개 (기업연도 408개)를 분석 대상으로 선정하였다. 3$)$ 분석 결과, 시장가치-장부가치 비율 $(\mathrm{M} / \mathrm{B}$ equity)의 평균과 중간값은 각각 0.654 와 0.452 로 1 보다 훨씬 낮은 수준을 나타내고 있어 이들의 기업가치가 상당히 낮게 형성되어 있음을 알 수 있었다. 반면 비지주회사의 M/B equity의 평균과 중간값은 각각 2.353 과 0.952 로 지주회사와 비교해 높은 기업가치를 나타내었다.

지주회사 저평가 현상을 정밀하게 분석하기 위해 $\mathrm{M} / \mathrm{B}$ equity를 종속변수로 한 기업가치 회귀분석을 실시하였다. 기업가치에 영향을 미치는 여러 기업특성을 통제한 후 회귀식을 추정한 결과, 지주회사 더미변수는 유의적인 음의 계수값을 나타내어 지주회사의 저평가 현상을 확인할 수 있었다. 특히 지주회사 더미변수의 계수값은 - 0.3 보다 낮은 값을 나타내었는데, 이는 기업특성을

1) 2017년 「독점규제 및 공정거래법에 관한 법률 시행령」 개정으로 지주회사의 최소 자산총액 기준은 기존 1 천억 원 이상에서 5 천억 원 이상으로 상향되었다.

2) 공정거래법상 지주회사를 순수지주회사로 간주한다면, 미국에서는 순수지주회사의 예를 찾기 힘들다. $\mathrm{GE}$ 는 순수지주회사라기 보다는 항공기엔진, 발전, 의료기기 등의 다각화된 사업을 영위하는 사업회사의 성격이 크며 Berkshire Hathaway는 손해보험업을 주 사업으로 영위하는 사업지주회사로 볼 수 있다. 일본의 경우(독점금지법의 정의를 따라) 순수지주회사를 별도 총자산의 $50 \%$ 이상이 종속 또는 관계회사 보유지분인 회사로 정의한다면 2019년 6월 현재 100 개가 넘은 순수지주회사가 상장되어 있는 것으로 보인다. 하지만, 한국과는 달리 일본은 지주회사에 대해 최소 자산규모 등의 법적 설립요건을 두거나 부채비율이나 자회사 최소 지분 보유율 등의 행위제한을 가하고 있지 않다(Ko, 2008). 따라서 일본의 순수지주회사를 한국의 공정거래법상 지주회사와 동등하게 취급하는 것은 무리일 수 있다.

3 ) 이는 비상장 지주회사( 75 개)와 금융지주회사(10개)를 제외한 결과이다. 
The Holding Company Discount in Korea's Stock Market

통제한 후에도 지주회사의 $\mathrm{M} / \mathrm{B}$ equity값이 다른 기업에 비해 평균적으로 0.3 이상 낮다는 의미이므로 지주회사 저평가 규모가 경제적으로도 유의함을 알 수 있었다.

다음으로 지주회사가 자신이 지배하는 자·손자회사에 비해서 저평가 되어 있는지 분석하였다. 분석 결과, 지주회사 $\mathrm{M} / \mathrm{B}$ equity의 평균과 중간값은 자·손자회사에 비해 유의적으로 낮았으며, 자·손자회사들의 평균과 중간값은 각각 1.919 와 1.169 로 높은 수준이여서 이들에게는 저평가 현상이 없는 것으로 보인다. 따라서 지주회사 디스카운트는 지주회사 체제를 취하고 있는 기업집단 소속 기업 전체에 나타나는 현상은 아니며, 지주회사에만 국한된 현상인 것으로 보인다. 그리고 지주회사가 수익성, 성장성 등의 기업펀더멘탈에 비해서도 저평가 되어 있는지 분석하기 위해 Campello and Graham(2009)의 회귀모형을 추정한 후 회귀식의 추정오차를 “실제 기업가치”와 "기업펀더멘탈을 반영한 적정가치" 간 괴리를 나타내는 측정치로 사용하였다. 분석 결과 지주회사의 회귀식 추정오차는 평균과 중간값 모두 유의적인 음의 값을 나타내었으며, 이는 지주회사의 기업가치가 기업펀더멘탈 대비 저평가 되어 있음을 시사한다.

공정거래법상 지주회사가 아닌 사실상의 지주회사-자사 고유사업을 영위하면서 기업집단 계열사를 지배통제하는 역할을 하는 사업지주회사-에게도 기업가치 디스카운트 현상이 나타 나는가를 분석한 결과 사실상 지주회사의 $\mathrm{M} / \mathrm{B}$ equity의 평균과 중간값은 각각 2.530 과 1.016 으로 높은 값을 나타내었으며, 기업가치 회귀분석 결과 사실상 지주회사에게는 기업가치 디스카운트 현상이 나타나지 않았다. 이는 투자자들이 고유사업을 영위하는 사업지주회사에게는 낮은 기업가치를 부여하지 않음을 시사한다.

지주회사 디스카운트의 원인을 탐구하기 위해 지주회사에 대한 투자자들의 투자관심도가 낮은지를 분석하였다. 주식의 가치는 투자자의 수요에 의해 결정됨에 비추어 (i) "투자자들은 지주회사 주식을 매력 있는 투자대상으로 생각하지 않아 투자관심도가 낮다” 그리고 (ii) “낮은 투자관심도는 지주회사가 단독상장 되어 있는 경우에 비해 자·손자회사와 함께 공동상장되어 있는 경우에 더 심하다”는 예측을 해 보았다. 투자자의 투자관심도를 나타내는 측정치로 주식의 거래회전율을 분석한 결과 평균과 중간값 모두 지주회사가 비지주회사보다 유의적으로 낮았다. 이는 지주회사에 대한 투자자들의 낮은 투자관심도가 지주회사 디스카운트의 원인 중 하나일 것이라는 가능성을 제기한다. 또한 지주회사 단독상장의 경우가 많지 않아 신뢰성 있는 통계적 결론이 어렵긴 하지만 단독상장 지주회사는 - 공동상장 지주회사에 비해-거래회전율이 유의 적으로 높고 기업가치 디스카운트 현상이 없거나 디스카운트의 규모가 작았다. 지주회사의 대부분이 적어도 하나의 자·손자회사와 공동상장 되어 있는 것에 비추어 이는 투자자의 수요가 지주회사로부터 사업자회사 쪽으로 집중되기 때문에 지주회사 디스카운트가 발생하거나 악화 된다는 설명을 지지하는 관측이다.

본 연구의 의의는 지주회사 디스카운트 현상에 대해 종합적이고 엄밀한 분석을 실시하여 디스카운트 현상의 통계적·경제적 유의성을 확인하였다는데 있다. 또한 지주회사 디스카운트를 초래하는 원인으로 지주회사에 대한 투자자의 관심이 저조함을 나타내는 증거를 제시하였다. 추가 분석 결과 지주회사가 사업회사로 존재하던 기간에는 기업가치가 높고 주식의 거래회전율도 높지만, 지주회사로 전환 후에는 기업가치와 거래회전율이 큰 폭으로 낮아지는 현상을 발견 
한국증권학회지 제48권 6호 (2019)

하였는데, 이는 고유사업이 없고 자회사 통제관리를 주목적으로 하는 지주회사를 투자자들은 매력적인 투자대상으로 생각하지 않는다는 해석을 지지한다.

한편 기업가치가 낮아지는 원인으로써 기업지배구조 등의 대리인 비용을 고려할 수 있으나, 공정거래법상 지주회사가 그들의 자·손자회사 또는 사실상의 지주회사에 비해 기업지배구조가 체계적으로 더 나쁠 것이라 볼 수 있는 선험적인 근거는 찾기 어려우며, 대리인 비용의 대용변수 로써 지배-소유 괴리도를 통제한 후 분석하여도 지주회사 디스카운트의 유의성은 유지되었다. 또한 지주회사에 대한 법률적 행위 제한이 지주회사 디스카운트의 일부를 설명할 수 있을지 몰라도 주된 이유는 아닌 것으로 판단된다. 일본의 순수지주회사에 대한 최근 연구(Kim et al., 2019)에 의하면 일본의 순수지주회사의 기업가치는 고유사업을 영위하는 사업모회사들에 비해 저평가 되어 있지 않기 때문에 지주회사 디스카운트는 한국시장의 특유한 현상인 것으로 추측된다.

본 논문의 구성은 다음과 같다. 제 1 장의 서론에 이어 제 2 장에서는 연구질문을 제시하고 관련 선행연구를 살펴본다. 제 3 장은 자료, 주요 변수, 분석모형을 기술한다. 제 4 장은 실증분석 결과를 보고·해석한다. 제 5 장에서는 논문의 한계를 서술하고 향후 연구방향을 제시한다.

\section{2. 연구 질문 및 관련 연구}

\section{1 연구 질문}

본 연구의 중심 질문은 지주회사가 다른 상장기업에 비해 저평가 되어 있는지 여부이다.4) 그런데 지주회사 저평가 여부를 엄밀하게 판단하기 위해서는 지주회사를 다른 상장회사와 비교하여 기업가치 분석을 실시하는 작업(아래 연구질문 1) 뿐 아니라 자회사와 손자회사에 비해 낮은 기업가치를 가지는지(아래 연구질문 2), 자신의 기업펀더멘탈에 비해 낮은 기업가치를 가지는지(아래 연구질문 3), 사실상의 지주회사 비해 낮은 기업가치를 가지는지(아래 연구질문 4) 등의 여부도 종합적으로 분석하는 작업이 필요하다.

연구질문 1: 지주회사는 그 밖의 상장기업에 비해 기업가치가 낮은가?

연구질문 2: 지주회사는 기업집단 내 자·손자회사에 비해 기업가치가 낮은가?

연구질문 3: 지주회사는 기업펀더멘탈을 반영한 적정가치에 비해 기업가치가 낮은가?

연구질문 4: 지주회사는 사실상의 지주회사에 비해 기업가치가 낮은가?

위 분석을 통해 지주회사의 저평가 현상이 통계적인 사실로 밝혀진다면, 그 원인을 찾는 작업이 수행되어야 한다. 이 원인을 객관적으로 밝히기는 어려운 일일 것이나, 본 연구에서는

4) 이 연구질문은 펀드의 시장가치가 순자산가치(NAV)에 비해 낮은지를 분석하는 closed-end fund discount 현상에 대한 연구(e.g., Lee et al., 1990)와는 성격이 다르다. 그리고 지주회사 보유 계열사 지분의 시장가치와 순자산가치(NAV)를 비교하는 연구방법은 실행에 있어 계산의 어려움이 있다. 먼저 지주회사가 보유한 계열사지분의 순자산가치(NAV)는 다수의 계열사가 비상장이기 때문에 계산이 힘들며 또한 지주회사는 보유지분 외에 다른 자산도 가지고 있어 보유 계열사지분의 시장가치를 별도로 분리해 내는 작업이 쉽지 않다. 
The Holding Company Discount in Korea's Stock Market

투자자들이 지주회사를 매력적인 투자대상으로 간주하지 않아 지주회사 디스카운트가 일어날 가능성을 탐구하기 위해 지주회사에 대한 투자자의 투자관심 정도를 분석하고자 한다.

연구질문 5: 투자자들은 지주회사에 낮은 투자관심도를 보이는가?

위 질문에 대답하기 위해 주식의 거래회전율 크기를 투자관심도의 대용변수로 사용해 지주회사의 거래회전율이 비지주회사에 비해 낮은지 분석한다.

\section{2 관련 선행 연구}

1999년 공정거래법 개정으로 지주회사의 설립 및 전환이 허용된 후 지주회사에 대한 연구가 본격적으로 시작되어 학술지 게재논문 또는 연구보고서의 형태로 발표되었다. Choi(2000)는 지주회사 체제가 연착륙을 위한 사업포트폴리오 구축과 재무정책 등으로 제안하면서 미국의 $\mathrm{GE}$ 나 스위스의 $\mathrm{ABB}$ 와 같은 그룹의 본사를 모범사례로 소개한다. Jung(2008)은 2000 2006년 기간 공정거래법상 지주회사 체제 기업집단을 상호출자제한 기업집단과 비교분석한 후 지주회사 체제 기업집단의 경영성과와 기업가치가 더 높다고 보고한다. Ra and Koh(2009)는 지주회사 전환 후 자. 손자회사의 재무구조가 향상되었으며 $\mathrm{LG}$ 와 GS를 사례연구로 분석하여 이들의 주가와 기업가치가 상승하였다고 보고하였다. 이와 유사하게 Kwak and Choi(2008)도 지주회사 전환 이후 자회사들이 이전에 비해 ROA 및 총자산이 유의하게 증가하였다고 보고하였다. 지주회사 전환의 공시 전후 주가수익률을 단기적으로 비교한 논문으로는 Baek and Park(2010)이 있는데 저자들은 지주회사 전환 정보가 긍정적인 공시효과로 나타난다고 보았다. 한편, Kim et al.(2014)은 장기(5년) 주가수익률을 분석하였는데, 지주회사 전환기업이 매칭기업에 비해 오히려 열등한 결과를 보인다고 하였다. Kim et al.(2009)은 지주회사 전환기업의 재량적 발생액이 양의 값을 나타내어 이들의 이익을 상향 조정한다는 증거를 보고한다. Choi and Lim(2009)은 지주회사 소속사의 지배구조가 통제기업에 비해 사외이사비율, 재무전문가 등의 면에서 좋으나, 두 집단 간 이익조정의 유의적 차이는 없다고 보고한다. 지주회사의 수익구조를 분석한 Lee (2014)는 지주회사들의 영업수익의 상당부분이 배당수익, 브랜드수수료, 임대수익 등의 형태로 자회사로부터 수취되고 있지만 이에 대한 가격 적정성 등의 판단이 어려우며 세부적인 내용에 대한 공시가 충분치 못한 상황이라고 주장하였다.

하지만 기존 학술지 게재 논문 중에는 지주회사의 기업가치 저평가 현상을 분석한 논문은 아직까지 없는 것으로 보인다.5) 한편 공정거래법상 지주회사를 순수지주회사로 이해한다면 이는 미국에는 존재하지 않는 회사 형태이기 때문에 따라서 지주회사 기업가치에 대한 미국의 선행연구는 없다. 물론 비슷한 이슈로 '다각화기업의 디스카운트(conglomerate discount)'에

5) 연구소 보고서 중에는 $\mathrm{Gam}(2002)$ 이 지주회사 디스카운트 문제를 다루고 있으나 공정거래법상 지주회사가 아닌 대규모 기업집단의 사업지주회사를 분석한 것으로 보인다. Shin et al.(2018)은 지주회사 전환기업과 소속 기업집단의 장기 주가수익률과 시가총액 증가율을 분석하였는데, 이는 지주회사의 타 기업 대비 저평가 여부와는 다른 주제이다. 
한국증권학회지 제48권 6호 (2019)

대한 많은 선행연구(e.g., Berger and Ofek, 1995)가 존재하지만 여기서 다각화기업은 여러 사업부문을 거느린 사업회사로 정의되기 때문에 자·손자회사를 통제하는 순수지주회사와는 다른 개념이다. 그런데 지주회사는 기업집단 내 모회사 역할을 하기 때문에 관련 연구로써 Almeida et al.(2011)의 연구를 언급할 필요가 있다. 이 저자들은 1999 2004년 기간의 한국의 대규모 기업집단 소속 기업을 대상으로 centrality (해당 회사의 계열사 지분이 지배주주의 기업 집단 통제에 기여하는 정도)와 Tobin's $\mathrm{Q}$ 로 측정한 기업가치 간에는 음의 관계가 있음을 보고한다. 이 관측은 계열사 지분을 많이 보유해 centrality가 높은 지주회사는 기업가치가 낮을 가능성을 시사한다.

한편 한국과 비슷한 시기인 1997년에 지주회사 전환과 설립을 법률적으로 허용한 일본에서는 지주회사의 수가 꾸준히 늘고 있다(Shimotani, 2012; 山田和延, 2014).6) 하지만 지주회사의 재무적 특성과 회계처리에 관련된 선행연구는 있지만, 다소 놀랍게도 지주회사의 기업가치 고평가 또는 저평가에 대한 연구는 일본의 학술지 게재논문 중에는 없다.7) 미게재 연구인 Kim et al.(2019)이 이 주제를 다루고 있는데 이 저자들의 분석결과는 본 논문 제 4장 제 8절에서 서술하기로 한다.

\section{3. 자료, 주요 변수 및 분석모형}

\section{1 자료}

연구표본 구축을 위해 FnGuide의 재무제표와 주가자료를 사용하였다. 먼저 2002 2017년 기간 코스피와 코스닥 시장에 상장된 회사를 대상으로 이 중 금융회사(산업분류코드 64-66)와 정부출자 공기업(산업분류코드 35)은 제외하였으며 총자산, 매출액 또는 산업분류코드 자료가 누락된 기업연도와 자본잠식 기업연도(즉, 자본총계가 음인 경우)도 표본에서 제외하였다. 본 연구의 가치평가 측정치인 M/B equity의 값이 50을 초과하는 기업연도도 극단치 통제를 위해 제외하였다. 또한 기업가치 회귀식에 사용되는 종속·설명 변수에서 결측치가 있는 기업연도 또한 제외하였다. 지주회사(즉, 공정거래법상 지주회사)는 공정거래위원회 웹사이트(www.ftc.go.kr)의 지주회사 리스트를 이용해 지주회사 여부를 판단하였다. 지주회사는 기존 사업회사가 인적분할, 물적분할, 주식의 포괄적 이전 등의 전환을 통해 설립되며 이에 따라 기업집단은 공정거래법상 지주회사 체제로 전환되는데, 전환 전의 기업집단에 속한 기업연도는 표본에서 제외하였다. 이 과정을 거쳐 최종 표본에 포함된 총 기업 수는 기업연도 21,488 개(고유기업 2,319 개)이며 이 중 지주회사는 기업연도 408개(고유기업 68개)이다. 최종 표본을 구축하는 상세한 과정은 <부록 1> 패널 A에 서술되었다. 최종 표본에 포함된 기업의 연도별 분포와 산업별 분포는 각각 <부록 1 > 패널 $\mathrm{B}$ 와 패널 $\mathrm{C}$ 에 제시되었다.

6) 일본의 지주회사에 대한 개괄적인 설명과 정보는 jp.wikipedia.com에서 持株會社를 검색어로 사용해 얻을 수 있다.

7) 이는 본 논문의 저자들이 인터넷 검색을 거친 후 일본의 기업재무 연구자들을 통해 확인하였다. 
The Holding Company Discount in Korea's Stock Market

최종 표본은 지주회사 외에도 그들의 자회사와 손자회사를 포함한다. 최종 표본 중 공정거래법상 지주회사 체제를 취하고 있는 기업집단에 소속된 기업의 수는 기업연도 1,496개(고유기업 249개) 이며 이 중에는 자회사는 기업연도 925 개(고유기업 154개), 손자회사는 기업연도 163 개(고유기업 27 개)이다(<부록 $1>$ 패널 D 참조). 기업집단 소속 자회사와 손자회사의 판별은 공정거래위원회의 웹사이트 자료를 사용하여 실시하였다. 한편 상장기업 중에는 공정거래법상 지주회사는 아니지만 기업집단의 지주회사 역할을 하는 사업회사가 존재한다. 이들을 선별하기 위해 공정거래위원회 웹사이트의 대규모기업집단 소유지분도 자료를 바탕으로 각 기업집단의 소유지분도 상 최상위 기업들을 사실상 지주회사로 인식하였다. 그 결과 총 18 개(264개 기업연도)의 기업이 사실상 지주회사로 선정되었다(<부록 $1>$ 패널 $\mathrm{E}$ 참조).8)

\section{2 변수와 연구방법}

본 연구는 지주회사 디스카운트 여부를 판단하기 위해 지주회사의 기업가치를 다른 상장회사 등과 비교하는데, 기업가치의 측정치로는 자기자본의 시장가치-장부가치 비율(M/B equity)을 사용한다. 장부가치는 연결재무제표와 별도재무제표 수치가 존재하지만, 주식시장의 투자자와 애널리스트가 주로 연결재무제표를 사용해 가치평가와 기업분석을 하고 있는 점을 감안해 연결재무제표의 장부가치를 계산에 사용한다. 기업재무 분야에서 자기자본 시장가치-장부가치 비율을 주된 기업가치 측정치로 사용하는 것은 매우 일반적이다.9) 실증 결과에 보고하지는 않았지만, 본 연구는 총자산 시장가치-장부가치 비율(이른바 Tobin's Q)을 대체적인 기업가치 변수로 사용해 분석을 하였으나 결과는 질적으로 대동소이하였다.

지주회사의 기업가치 평균과 중간값을 다른 상장회사 등과 비교하는 단변량분석(t-test와 Wilcoxon's Z-test)을 실시한 후, 기업가치에 영향을 미치는 여러 변수를 통제한 기업가치 회귀식을 추정하는데, 이 회귀식은 다음과 같다.

$$
M / B \text { equity }_{i, t}=\beta_{0}+\beta_{1} \cdot \text { Holding Dummy } y_{i, t}+\beta_{2} \cdot x_{i, t}+u_{t}+\epsilon_{i, t}
$$

Holding Dummy $y_{i, t}$ 는 지주회사 더미변수이며 지주회사는 1 , 나머지 상장회사는 0의 값을 가진다. 지주회사가 저평가 현상을 나타내는가 여부는 이 더미변수의 계수인 $\beta_{1}$ 의 값을 통해 판단한다. $x_{i, t}$ 는 통제변수 벡터이며 기업규모 $(\log ($ Assets $))$, 설비투자규모 $(\Delta \mathrm{PPE} / \mathrm{lag}$ Sales), 영업이익률 (EBIT/Sales), 부채비율(Leverage), 주가수익률 변동성(Volatility)을 포함한다.10) $u_{t}$ 는 기업

8) 연구표본에 포함된 사실상 지주회사는 공정거래위원회가 감시하는 대규모 기업집단 중 공정거래법상 지주회사 체제로 전환하지 않은 기업집단 소속 기업 중 소유구조상 최상위 기업이라고 이해할 수 있다. 삼성그룹, 현대차그룹, 롯데그룹 등은 순환출자 때문에 소유지분도 상 최상위 기업의 판별이 어려워 소속회사를 사실상 지주회사에 포함하지 않았다.

9) 예로써 Pástor and Veronesi(2003)와 Chay et al.(2015)을 들 수 있으며 Fama and French(2015)의 3 요인 또는 5 요인모형의 가치주·성장주 분류도 시장가치-장부가치 비율(또는 그의 역수)을 기준으로 이루어진다.

10) 이 통제변수들은 Berger and Ofek(1995)에서 기업가치에 영향을 미치는 변수로 서술되었으며 Mansi and Reeb(2002) 등의 후속연구에서 기업가치 회귀식의 통제변수로 사용되었다. 
한국증권학회지 제48권 6호 (2019)

연도 고정효과이다.11) 아래첨자 $\mathrm{i}$ 와 $\mathrm{t}$ 는 각각 기업과 연도를 나타낸다. 위 기업가치 회귀식에 사용된 변수의 정의는 <부록 $2>$ 에 제시되었다.

지주회사 더미변수와 관련된 변수로 별도 총자산에서 계열사 지분이 차지하는 비중(Eqt. Stake/Assets)과 별도 매출액에서 배당수입이 차지하는 비중(Div. Income/Sales)을 고려할 수 있다.12) 공정거래법 규정상 지주회사는 계열사 지분을 별도 총자산의 $50 \%$ 이상으로 보유해야 하며 자사 고유사업의 매출창출 비중이 낮기 때문에 배당수입이 매출에서 차지하는 비중이 높을 것으로 예상된다. 본 연구는 Eqt. Stake/Assets과 Div. Income/Sales가 기업가치와 어떤 관련성을 나타내는지 분석함으로써 지주회사 저평가 여부와 원인에 대한 더 깊은 이해를 구하고자 한다.

지주회사 기업가치의 저평가 여부는 '기업펀더멘탈에 비해서 기업가치가 낮은가'라는 관점에서 분석할 수도 있다. 기업펀더멘탈을 반영한 적정한 기업가치를 객관적으로 추정하기는 힘들지만, 본 연구에서는 Campello and Graham(2013)의 회귀식의 추정치를 적정 기업가치의 대용치로 사용한다. Campello and Graham(2013)은 수익성과 성장성 등을 나타내는 다양한 기업특성을 설명변수로 사용하는데, <부록 $2>$ 에 설명변수와 각각의 정의를 제시하였다. 본 연구의 최종 표본에 대해 Campello and Graham(2013)의 회귀식을 추정한 결과는 <부록 3>에 보고하였다. 이 회귀식의 추정오차는 실제 기업가치와 추정 적정가치의 차이이므로 기업가치가 펀더멘탈로 부터 괴리되어 있는 정도를 나타내는 측정치로 가정하고 분석하기로 한다.

\section{4. 실증분석 결과}

\section{1 기초통계량 분석: 지주회사 vs. 비지주회사}

<표 1>은 표본기업을 공정거래법에 따라 설립된 지주회사(i.e., 지주회사)와 그 밖의 회사(i.e., 비지주회사)를 두 집단으로 구분하여 기업가치와 주요 기업특성을 비교한다. 표의 첫 행은 기업가치 측정치인 자기자본 시장가치-장부가치 $(\mathrm{M} / \mathrm{B}$ equity)의 평균과 중간값을 보고하는데, 지주회사의 평균과 중간값(0.654와 0.452)이 모두 비지주회사의 값(2.353과 0.952)보다 유의적 으로 낮아 지주회사 저평가 현상이 존재함을 시사하고 있다. 특히 지주회사의 M/B equity는 평균과 중간값 모두 1 보다 매우 낮은 값을 나타내고 있어 지주회사가 장부가치 대비 매우 낮은 가격에 거래되는 현상을 보여주고 있다.

11) 본 연구는 "지주회사 vs. 비지주회사" 또는 "지주회사 vs. 자·손자회사"의 구분이 횡단면 기업가치 분포를 설명할 수 있는가를 분석하는 것이 목적이기 때문에 회귀식에 기업고정효과를 통제하지 않았다. Pástor and Veronesi(2003)도 비슷한 이유로 기업가치 회귀분석에서도 기업고정효과를 통제하지 않았다. 또한 회귀식의 주 설명변수인 지주회사 더미가 시간고정변수(time-invariant variable)이기 때문에 기업고정효과모형이 지주회사 더미의 기업가치 효과를 제대로 추정하지 못할 수 있다.

12) 본 연구에서는 계열사는 종속회사-관계회사-공동회사를 포괄하는 개념으로 사용하며, 따라서 계열사 지분은 (별도 재무상태표에 보고된) 종속회사·관계회사·공동회사 지분의 합계이다. 
The Holding Company Discount in Korea's Stock Market

〈표 1〉 지주회사 Vs. 비지주회사: 기초통계량

표본을 지주회사와 비지주회사의 두 집단으로 나누어 기초통계량을 비교한다. 표본은 2002 2017 기간 상장기업을 대상으로 <부록 $1>$ 의 절차를 따라 완성하였다. 지주회사는 공정거래법에 따라 설립된 지주회사를 의미하며, 비지주회사는 지주회사를 제외한 나머지 표본기업을 의미한다. 기업가치 측정치인 $\mathrm{M} / \mathrm{B}$ equity는 자기자본의 시장가치-장부가치 비율을 의미하며, 장부가치는 연결재무제표상 장부가치이다. 다른 변수의 정의는 <부록 $2>$ 에 제시되었다. 모든 연속변수는 분포의 상하위 각각 $1 \%$ 에서 윈저라이저 하였다. 관측치수는 해당 집단의 기업연도 수를 의미한다. 평균과 중간값에 대한 차이 검증은 $\mathrm{t}-\mathrm{test}$ 와 Wilcoxon's Z-test이다. *, **, ***는 각각 $10 \%, 5 \%, 1 \%$ 수준의 양측검정 유의성을 의미한다.

\begin{tabular}{|c|c|c|c|c|c|c|c|c|c|c|}
\hline & \multicolumn{4}{|c|}{ 지주회사 } & \multicolumn{4}{|c|}{ 비지주회사 } & \multicolumn{2}{|c|}{ 차이 검증 } \\
\hline & $\begin{array}{l}\text { 관측 } \\
\text { 치수 }\end{array}$ & 평균 & 중간값 & $\begin{array}{l}\text { 표준 } \\
\text { 편차 }\end{array}$ & $\begin{array}{l}\text { 관측 } \\
\text { 치수 }\end{array}$ & 평균 & 중간값 & $\begin{array}{l}\text { 표준 } \\
\text { 편차 }\end{array}$ & $(2)-(6)$ & (3) $-(7)$ \\
\hline & (1) & (2) & (3) & (4) & (5) & (6) & (7) & (8) & (9) & (10) \\
\hline$\overline{\mathrm{M} / \mathrm{B} \text { equity }}$ & 408 & 0.654 & 0.452 & 0.962 & 21,080 & 2.353 & 0.952 & 5.000 & $-1.699^{* * * *}$ & $-0.500^{* * *}$ \\
\hline Eqt. Stake/Assets & 408 & 0.755 & 0.816 & 0.149 & 21,080 & 0.106 & 0.045 & 0.147 & $0.649^{* * * *}$ & $0.771^{\text {**** }}$ \\
\hline Div. Income/Sales & 408 & 0.177 & 0.212 & 0.153 & 21,080 & 0.003 & 0.000 & 0.021 & $0.174^{* * *}$ & $0.212^{* * *}$ \\
\hline $\log$ (Assets) & 408 & 27.887 & 27.711 & 1.297 & 21,080 & 25.653 & 25.388 & 1.453 & $2.234^{* * *}$ & $2.324^{* * * *}$ \\
\hline$\Delta \mathrm{PPE} / \mathrm{lag}$ Sales & 408 & 0.039 & 0.011 & 0.209 & 21,080 & 0.035 & 0.004 & 0.171 & 0.004 & $0.007^{* *}$ \\
\hline EBIT/Sales & 408 & 0.076 & 0.061 & 0.074 & 21,080 & 0.006 & 0.041 & 0.215 & $0.070^{* * *}$ & $0.020^{* * *}$ \\
\hline Leverage & 408 & 0.230 & 0.225 & 0.170 & 21,080 & 0.226 & 0.207 & 0.180 & 0.005 & 0.018 \\
\hline Volatility & 408 & 38.338 & 36.008 & 14.487 & 21,080 & 54.409 & 51.191 & 21.469 & $-16.071^{* * *}$ & $-15.183^{* * *}$ \\
\hline
\end{tabular}

<표 1>의 두 번째와 세 번째 행은 계열사지분 크기(Eqt. Stake/Assets)와 배당수입 크기(Div. Income/Sales)를 보고하는데 지주회사의 Eqt. Stake/Assets와 Div. Income/Sales의 평균값이 각각 0.755 와 0.177 로 비지주회사의 평균값 0.106 과 0.003보다 상당히 높은 수준으로 나타났다.

표의 나머지 변수들은 이후 추정될 기업가치 회귀분석의 통제변수로 사용될 기업특성들이며 모두 연결재무제표를 사용해 계산되었다.13) 기업규모를 나타내는 총자산의 로그값( $\log (\operatorname{Assets}))$ 의 경우 지주회사가 비지주회사보다 평균과 중간값에서 모두 높아 지주회사가 비지주회사에 비해서 기업규모가 큰 편이다. 기업의 투자성향 또는 성장률을 나타내는 전기 매출액 대비 유형고정자산의 증가( $\triangle \mathrm{PPE} / \mathrm{lag}$ Sales)는 지주회사가 비지주회사에 비해 평균은 근소하게 높으나 중간값은 유의적으로 높다. 영업수익성을 측정하는 매출액 대비 영업이익률(EBIT/Sales)은 평균과 중간값 모두 지주회사가 비지주회사보다 유의적으로 높다. 이와 같은 지주회사의 상대적으로 높은 성장률과 수익성은 지주회사의 기업가치 저평가가 그들의 성장률과 수익성 특성에 기인하지 않음을 시사한다. 한편 지주회사의 부채비율(Leverage)은 비지주회사와 비교해 유의적인 차이를 나타내지 않는 반면 주가수익률 변동성(Volatility)은 비지주회사에 비해 평균과 중간값 모두에서 상당히 낮은 현상을 보이고 있다.

$<$ 표 2>는 기초통계량 분석에 포함된 변수를 대상으로 변수 간 상관계수를 보고한다. 또한 지주회사 더미변수(Holding Dummy)를 변수로 추가해 지주회사 여부가 다른 변수들과 어떤 상관관계를 가지는가 분석한다. Holding Dummy는 지주회사는 1 , 그 밖의 기업에는 0 의 값을

13) 연결재무제표를 발표하지 않아 개별재무제표만 구할 수 있는 기업의 경우는 개별재무제표를 사용 하였다. 
한국증권학회지 제48권 6호 (2019)

부여하는 더미변수이다. Holding Dummy와 M/B equity는 유의적인 음의 상관관계(-0.047)를 나타내어 지주회사의 기업가치가 낮은 현상을 지지한다. 또한 Holding Dummy는 보유 계열사 지분 규모와 배당수입 규모와 유의적인 상관관계를 나타내어 지주회사가 타 기업에 비해 계열사지분을 많이 보유하고 있고 매출의 상당 부분을 배당수입에 의존하고 있는 상황을 반영하고 있다.

〈표 2〉변수 간 상관관계 분석

표는 가치평가 회귀분석에 사용되는 변수 간의 피어슨 상관계수를 보고한다. 괄호 안의 수치는 확률값이다. 표본은 2002 2017 기간 상장기업을 대상으로 <부록 1>의 절차를 따라 완성하였다. Holding Dummy는 지주회사 더미변수이며 공정거래법에 따라 설립된 지주회사의 경우에는 1 , 나머지 모든 상장회사는 0 의 값을 가진다. 그 밖의 변수의 정의는 <부록 $2>$ 에 제시되었다. 모든 연속변수들은 상하위 각각 $1 \%$ 에서 윈저라이저하였다.

\begin{tabular}{|c|c|c|c|c|c|c|c|c|c|}
\hline & (1) & (2) & (3) & (4) & (5) & (6) & (7) & (8) & (9) \\
\hline (1) $\mathrm{M} / \mathrm{B}$ equity & 1.000 & & & & & & & & \\
\hline (2) Holding Dummy & $\begin{array}{l}-0.047 \\
(0.000)\end{array}$ & 1.000 & & & & & & & \\
\hline (3) Eqt. Stake/Assets & $\begin{array}{l}-0.017 \\
(0.013)\end{array}$ & $\begin{array}{r}0.516 \\
(0.000)\end{array}$ & 1.000 & & & & & & \\
\hline (4) Div. Income/Sales & $\begin{array}{l}-0.047 \\
(0.000)\end{array}$ & $\begin{array}{r}0.631 \\
(0.000)\end{array}$ & $\begin{array}{r}0.459 \\
(0.000)\end{array}$ & 1.000 & & & & & \\
\hline (5) $\log$ (Assets) & $\begin{array}{l}-0.164 \\
(0.000)\end{array}$ & $\begin{array}{r}0.206 \\
(0.000)\end{array}$ & $\begin{array}{r}0.319 \\
(0.000)\end{array}$ & $\begin{array}{r}0.212 \\
(0.000)\end{array}$ & 1.000 & & & & \\
\hline (6) $\triangle \mathrm{PPE} / \mathrm{lag}$ Sales & $\begin{array}{l}-0.003 \\
(0.633)\end{array}$ & $\begin{array}{r}0.003 \\
(0.636)\end{array}$ & $\begin{array}{r}0.018 \\
(0.008)\end{array}$ & $\begin{array}{l}-0.013 \\
(0.061)\end{array}$ & $\begin{array}{r}0.031 \\
(0.000)\end{array}$ & 1.000 & & & \\
\hline (7) EBIT/Sales & $\begin{array}{l}-0.238 \\
(0.000)\end{array}$ & $\begin{array}{r}0.045 \\
(0.000)\end{array}$ & $\begin{array}{l}-0.040 \\
(0.000)\end{array}$ & $\begin{array}{r}0.038 \\
(0.000)\end{array}$ & $\begin{array}{r}0.234 \\
(0.000)\end{array}$ & $\begin{array}{r}0.057 \\
(0.000)\end{array}$ & 1.000 & & \\
\hline (8) Leverage & $\begin{array}{r}0.113 \\
(0.000)\end{array}$ & $\begin{array}{r}0.004 \\
(0.596)\end{array}$ & $\begin{array}{r}0.091 \\
(0.000)\end{array}$ & $\begin{array}{l}-0.016 \\
(0.018)\end{array}$ & $\begin{array}{r}0.164 \\
(0.000)\end{array}$ & $\begin{array}{r}0.044 \\
(0.000)\end{array}$ & $\begin{array}{l}-0.153 \\
(0.000)\end{array}$ & 1.000 & \\
\hline (9) Volatility & $\begin{array}{r}0.274 \\
(0.000)\end{array}$ & $\begin{array}{l}-0.102 \\
(0.000)\end{array}$ & $\begin{array}{r}-0.070 \\
(0.000)\end{array}$ & $\begin{array}{l}-0.124 \\
(0.000)\end{array}$ & $\begin{array}{l}-0.427 \\
(0.000)\end{array}$ & $\begin{array}{r}0.009 \\
(0.206)\end{array}$ & $\begin{array}{l}-0.322 \\
(0.000)\end{array}$ & $\begin{array}{r}0.138 \\
(0.000)\end{array}$ & 1.000 \\
\hline
\end{tabular}

\section{2 기업가치 회귀분석을 통한 지주회사 디스카운트 분석}

앞서 기초통계량 분석을 통해 공정거래법상 지주회사는 다른 상장회사들에 비해 평균적으로 상당히 낮은 기업가치를 가진다는 현상을 알 수 있었다. 이 현상을 더 확인하기 위해 주요 기업특성을 통제한 다변량 회귀분석을 실시한다.

<표 3>은 지주회사 더미변수(Holding Dummy)를 주된 설명변수로 사용한 기업가치 회귀분석 결과를 보고한다. Holding Dummy는 지주회사는 1 , 그 밖의 기업에는 0 의 값을 부여하는 더미변수이다. 회귀식의 종속변수는 기업가치의 대용변수인 시장가치-장부가치 비율 $(\mathrm{M} / \mathrm{B}$ equity)이다. 통제변수로는 기초통계량 분석 시 보고된 다양한 기업특성변수를 포함하였으며 또한 연도고정효과를 추가하였다. 칼럼 (1)의 회귀식 추정 결과, Holding Dummy는 통계적으로 
The Holding Company Discount in Korea's Stock Market

유의적인 음의 계수값(-0.302)을 나타낸다. 이는 지주회사가 다른 상장회사에 비해 낮은 기업 가치를 가지는 현상이 다변량 회귀분석에서도 지지됨을 시사한다.

표의 칼럼 (2)와 칼럼 (3)은 계열사지분 크기(Eqt. Stake/Assets)와 배당수입 크기(Div. Income/ Sales)를 주된 설명변수로 사용한 회귀분석 결과를 보고한다. 칼럼 (2)의 회귀식 결과 Eqt. Stake/Assets의 계수값은 0.071로 유의적이지 않은 양의 값을 나타내어 “보유 계열사 지분이 클수록 기업가치가 낮다”는 예측은 지지되지 않는다. 또한 칼럼 (3)의 회귀식 결과 Div. Income/Sales의 계수값은 -0.366으로 음의 값을 가지나 유의적이지는 않아 "매출의 배당수입 의존도가 높을수록 기업가치가 낮다”는 예측은 지지되지 않는다. 이는 지주회사의 특성상 다른 회사들과 비교해 보유 계열사 지분이 크고 또한 배당금 수입이 높은 특성을 가지고 있음을 감안한다면 다소 의외의 결과이다.

\section{〈표 3〉기업가치 회귀분석: 지주회사 더미변수 포함}

표는 기업가치 회귀분석 결과를 보고한다. 표본은 2002 2017 기간 상장기업을 대상으로 <부록 1>의 절차를 따라 완성하였다. 종속변수는 기업가치 측정치인 $\mathrm{M} / \mathrm{B}$ equity(자기자본의 시장가치-장부가치 비율)이다. Holding Dummy는 지주회사 더미변수이며 공정거래법에 따라 설립된 지주회사의 경우에는 1 , 나머지 모든 상장회사는 0 의 값을 가진다. 변수의 정의는 <부록 $2>$ 에 제시되었다. 모든 연속변수는 분포의 상하위 각각 $1 \%$ 에서 윈저라이저하였다. 모든 회귀식은 연도고정효과를 통제하여 추정되었다. 관측치 수는 회귀식 추정에 포함된 기업연도 수를 의미한다. 괄호 안의 수치는 firm-clustered standard error를 사용한 t값이며 * ${ }^{* *},{ }^{* * *}$ 는 각각 $10 \%, 5 \%, 1 \%$ 수준의 양측검정 유의성을 의미한다.

\begin{tabular}{|c|c|c|c|c|}
\hline & \multicolumn{4}{|c|}{ 종속변수: M/B equity } \\
\hline & (1) & (2) & (3) & (4) \\
\hline Holding Dummy & $\begin{array}{l}-0.302^{*} \\
(-1.94)\end{array}$ & & & $\begin{array}{l}-0.493^{*} \\
(-1.93)\end{array}$ \\
\hline Eqt. Stake/Assets & & $\begin{array}{r}0.071 \\
(0.22)\end{array}$ & & $\begin{array}{r}0.247 \\
(0.58)\end{array}$ \\
\hline Div. Income/Sales & & & $\begin{array}{l}-0.366 \\
(-0.67)\end{array}$ & $\begin{array}{l}0.274 \\
(0.39)\end{array}$ \\
\hline $\log$ (Assets) & $\begin{array}{l}-0.160^{* * *} \\
(-3.20)\end{array}$ & $\begin{array}{l}-0.169^{* * *} \\
(-3.21)\end{array}$ & $\begin{array}{l}-0.164^{* * *} \\
(-3.26)\end{array}$ & $\begin{array}{l}-0.168^{* * *} \\
(-3.18)\end{array}$ \\
\hline$\triangle \mathrm{PPE} /$ lag Sales & $\begin{array}{l}0.177 \\
(0.71)\end{array}$ & $\begin{array}{c}0.177 \\
(0.70)\end{array}$ & $\begin{array}{l}0.176 \\
(0.70)\end{array}$ & $\begin{array}{c}0.176 \\
(0.70)\end{array}$ \\
\hline EBIT/Sales & $\begin{array}{l}-3.444^{* * * *} \\
(-9.68)\end{array}$ & $\begin{array}{l}-3.437^{* * *} \\
(-9.69)\end{array}$ & $\begin{array}{l}-3.444^{* * *} \\
(-9.68)\end{array}$ & $\begin{array}{l}-3.424^{* * *} \\
(-9.66)\end{array}$ \\
\hline Leverage & $\begin{array}{l}2.137^{* * * *} \\
(5.83)\end{array}$ & $\begin{array}{l}2.143^{* * *} \\
(5.84)\end{array}$ & $\begin{array}{l}2.140^{* * *} \\
(5.83)\end{array}$ & $\begin{array}{l}2.133^{* * *} \\
(5.78)\end{array}$ \\
\hline Volatility & $\begin{array}{c}0.048^{* * *} \\
(18.19)\end{array}$ & $\begin{array}{l}0.048^{* * * *} \\
(18.24)\end{array}$ & $\begin{array}{c}0.048^{* * * *} \\
(18.18)\end{array}$ & $\begin{array}{c}0.048^{* * * *} \\
(18.24)\end{array}$ \\
\hline Intercept & $\begin{array}{l}2.626^{* *} \\
(2.02) \\
\end{array}$ & $\begin{array}{l}2.841^{* *} \\
(2.08) \\
\end{array}$ & $\begin{array}{l}2.720^{* *} \\
(2.09) \\
\end{array}$ & $\begin{array}{l}2.825^{* *} \\
(2.07) \\
\end{array}$ \\
\hline 연도고정효과 & Yes & Yes & Yes & Yes \\
\hline 관측치 수 & 21,488 & 21,488 & 21,488 & 21,488 \\
\hline Adj. $R^{2}$ & 0.117 & 0.117 & 0.117 & 0.117 \\
\hline
\end{tabular}


한국증권학회지 제48권 6호 (2019)

<표 3>의 칼럼 (4)의 회귀식은 Holding Dummy를 Eqt. Stake/Assets와 Div. Income/ Sales와 함께 설명변수로 사용하는데, Holding Dummy가 유의적인 음의 계수값(-0.493)을

\section{〈표 4〉기업가치 회귀분석: 기업집단과 산업고정효과 추가}

표는 기업집단고정효과와 산업고정효과를 추가해 추정한 회귀식 결과를 보고한다. 표본은 2002 2017 기간 상장기업을 대상으로 <부록 $1>$ 의 절차를 따라 완성하였다. 종속변수는 기업가치 측정치인 $\mathrm{M} / \mathrm{B}$ equity(자기자본의 시장가치-장부가치 비율)이다. Holding Dummy는 지주회사 더미변수이며 공정거래법에 따라 설립된 지주회사의 경우에는 1 , 나머지 모든 상장회사는 0 의 값을 가진다. 회귀식에 추가된 통제변수들은 $\log$ (Assets), $\Delta \mathrm{PPE} / \mathrm{lag}$ Sales, EBIT/Sales, Leverage, Volatility이며 이들의 추정계수는 간결성을 위해 표에서 생략하였다. 변수의 정의는 <부록 $2>$ 에 제시되었다. 모든 연속변수는 분포의 상하위 각각 $1 \%$ 에서 윈저라이저하였다. 모든 회귀식은 연도고정효과를 통제하여 추정되었다. 패널 $\mathrm{A}$ 에서는 기업집단고정 효과를 통제하였으며, 패널 $\mathrm{B}$ 에서는 산업고정효과를 추가해 통제하였다. 산업고정효과는 $\mathrm{KSIC} 2$ digit 수준에서 통제되었다. 관측치 수는 회귀식 추정에 포함된 기업연도 수를 의미한다. 괄호 안의 수치는 firm-clustered standard error를 사용한 t값이며 *, *****는 각각 $10 \%, 5 \%, 1 \%$ 수준의 양측검정 유의성을 의미한다.

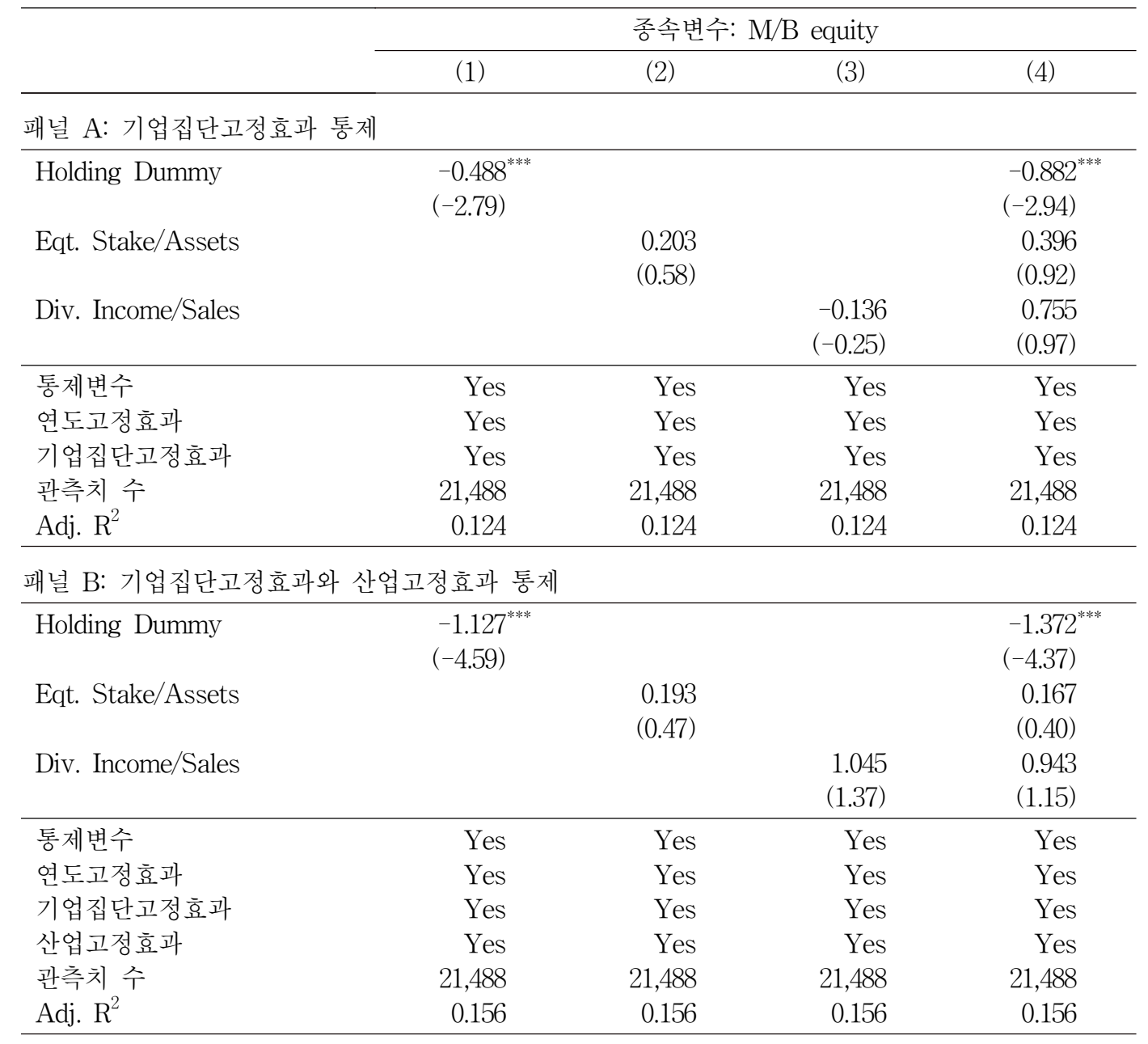


The Holding Company Discount in Korea's Stock Market

나타내어 지주회사 저평가 현상의 존재를 추가적으로 지지한다. 하지만 칼럼 (2)와 (3)에서 마찬가지로 계열사지분 크기와 배당수입 크기는 유의적인 계수값을 나타내지 않는다. 이 결과를 통해 다음과 같은 해석을 조심스럽게 해볼 수 있다: “한국주식시장의 투자자들은 공정거래법상 지주회사의 기업가치를 낮게 평가하지만, 회사의 계열사지분 크기 또는 배당수입 크기를 바탕으로 기업가치를 낮게 평가하지는 않는다."

<표 4>는 기업집단고정효과와 산업고정효과를 추가로 통제하여 가치평가 회귀식을 추정한 결과를 보고한다. 기업집단고정효과는-더미변수 개념을 사용해 설명하자면-동일한 기업 집단에 소속된 기업에게는 1 의 값을 그 밖의 기업에는 0 의 값을 부여하는 더미변수들을 회귀식에 추가한다는 것을 의미한다. 해당 기업이 특정 기업집단에 소속되는가의 판단은 공정거래위원회 웹사이트자료를 이용하였으며 산업고정효과는 KSIC 2 digit 수준에서 통제되었다.

$<$ 표 4>의 패널 $\mathrm{A}$ 는 기업집단고정효과를 추가한 추정 결과를 보고하는데, 지주회사 더미변수 (Holding Dummy)가 칼럼 (1)과 (4)에서 유의적인 음의 값을 나타내고 있어 지주회사 저평가 현상의 존재를 추가적으로 지지한다. 한편 칼럼 (2), (3), (4)에서 계열사 지분 크기(Eqt. Stake/ Assets)와 배당수입 크기(Div. Income/Sales)는 유의적인 계수값을 가지지 않아 <표 3>에서와 동일한 결과를 보고해 주고 있다. <표 $3>$ 의 패널 $\mathrm{B}$ 는 기업집단고정효과와 함께 산업고정효과를 통제한 결과를 보고하는데, 추정 결과는 계속해서 일관된 결과를 보고하고 있다. 즉, Holding Dummy는 유의적인 음의 값을 나타내어 지주회사 저평가 현상과 일관성이 있으나 계열사지분 크기와 배당수입 크기는 유의적인 계수값을 가지지 않는다.14)

회귀분석 결과를 정리하자면, 지주회사 더미변수의 계수값은 여러 회귀모형에서 일관되게 유의적인 음의 값을 나타내어 공정거래법상 지주회사가 다른 기업에 비해 저평가 되어 있는 현상을 지지한다. 특히 지주회사 더미변수의 음의 계수값은 모두 절대값으로 0.3 을 초과하는 수준이며 이는 기업특성을 통제한 후에도 지주회사의 시장가치-장부가치 값이 평균적으로 다른 기업에 비해 0.3 이상 낮음을 시사해 지주회사 저평가 규모가 경제적으로도 매우 유의적임을 알 수 있다.

\section{3 지주회사 vs. 자 손자회사 분석}

앞 절의 분석에서는 지주회사를 다른 상장회사와 비교해 지주회사의 기업가치가 저평가 되어 있는 현상을 보고하였다. 그런데 지주회사의 기업가치가 그들이 지배하고 있는 자회사와 손자회사에 비해 더 낮은 가치를 가지는가 여부도 분석할 필요가 있다. 물론 <표 $4>$ 의 기업가치 회귀분석에서 기업집단고정효과를 추가함으로써 지주회사의 기업가치가 동일 집단 소속 타 기업보다 저평가 되어 있는가 여부를 고려했다고 볼 수 있지만, 이 절에서는 더 직접적인 분석을 실시하고자 한다.

14 ) <부록 1> 패널 $\mathrm{C}$ 에 보고된 바와 같이 공정거래법상 지주회사의 대부분이 동일한 산업코드(코드 71)를 가진다. 따라서 회귀식에 산업고정효과를 추가하는 것은 지주회사 더미(Hold Dummy)를 설명변수로 사용하는 것과 거의 동일한 효과를 가지기 때문에 지주회사 더미의 추정 계수값의 불안정성이 높아져 추정 신뢰성이 훼손된다. 따라서 다음 절의 실증 결과부터는 산업고정효과를 추가한 회귀식 결과를 보고하지 않는다. 
한국증권학회지 제48권 6호 (2019)

<표 5>에서는 공정거래법상 지주회사와 그들이 지배하는 자회사와 손자회사만을 표본에 포함시켜 분석한다. 본 논문에서는 이 기업들을 통틀어 '지주회사 체제 기업집단 소속 기업'이라 부른다. <표 $5>$ 의 패널 $\mathrm{A}$ 는 지주회사 $\mathrm{M} / \mathrm{B}$ equity의 평균과 중간값( $(0.654$ 와 0.452$)$ 이 자·손자회사의 평균과 중간값(1.919와 1.169)에 비해 유의적으로 낮음을 보고한다. 따라서 지주회사의 저평가 현상은 그들의 자회사와 비교해서도 유의적임을 확인할 수 있다. 특히 자회사의 평균과 중간값은 1 보다 높은 점에 비추어 '지주회사 디스카운트 현상'은 지주회사에 국한된 현상이며 그들의 종속회사에는 나타나지 않는 현상으로 보인다.

<표 5>의 패널 B.1과 B.2에서는 지주회사 체제 기업집단 소속 기업만을 대상으로 기업가치 회귀식을 추정한다. 패널 B.1은 연도고정효과를 통제한 회귀식 결과를 보고하는데, 칼럼 (1)에는 앞서와 마찬가지로 지주회사 더미(Holding Dummy)의 계수값이 유의적인 음의 값을 나타내어 지주회사 디스카운트 현상을 추가적으로 확인할 수 있다. 그런데 칼럼 (2)와 (3)의 주 설명변수인 계열사 보유지분 크기(Eqt. Stake/Assets)와 배당수입 크기(Div. Income/Sales)의 계수값은 모두 유의적인 음의 값을 가지는데, 이는 앞서 <표 $3>$ 과 <표 $4>$ 의 회귀식에서 이들의 계수값이 유의하지 않은 것과는 대조적인 결과이다. 이는 전체 표본에서와는 달리, 지주회사 체제 기업집단

〈표 5〉지주회사 체제 기업집단: 지주회사 Vs. 자·손자회사

패널 $\mathrm{A}$ 는 공정거래법에 따라 설립된 지주회사가 통제하는 기업집단(이하 지주회사 체제 기업집단)에 소속된 기업을 지주회사와 자·손자회사로 구분하여 기업가치와 기업특성을 비교한다. 자·손자회사 중 자회사의 고유기업(기업연도) 수는 154(925)이며 손자회사는 27(163)이다. 표본은 2002 2017년 기간 상장기업을 대상으로 <부록 $1>$ 의 절차를 따라 완성하였다. 변수의 정의는 <부록 $2>$ 에 제시되었다. 패널 B.1는 지주회사 체제 기업집단 소속 기업에 대해 기업가치 회귀분석을 실시한 결과를 보고한다. 종속변수는 기업가치 측정치인 $\mathrm{M} / \mathrm{B}$ equity(자기자본의 시장가치-장부가치 비율)이다. Holding Dummy는 지주회사 더미변수이며 공정거래법에 따라 설립된 지주회사의 경우에는 1 , 그 밖의 회사는 0 의 값을 가진다. 회귀식에 추가된 통제변수들은 $\log$ (Assets), $\Delta \mathrm{PPE} / \mathrm{lag}$ Sales, EBIT/Sales, Leverage, Volatility 이며 이들의 추정계수는 간결성을 위해 표에서 생략하였다. 모든 회귀식은 연도고정효과를 통제하여 추정되었으며 패널 B.2에서는 기업집단고정효과를 추가적으로 통제하였다. 모든 연속변수는 분포의 상하위 각각 $1 \%$ 에서 윈저라이저하였다. 관측치 수는 기업연도 수를 의미한다. 괄호 안의 수치는 firm-clustered standard error를 사용한 t값이며 * ******는 각각 $10 \%, 5 \%, 1 \%$ 수준의 양측검정 유의성을 의미한다. 패널 $\mathrm{A}$ : 기초통계량

\begin{tabular}{|c|c|c|c|c|c|c|c|c|}
\hline & \multicolumn{3}{|c|}{ 지주회사 } & \multicolumn{3}{|c|}{ 자·손자회사 } & \multicolumn{2}{|c|}{ 차이 검증 } \\
\hline & $\begin{array}{l}\text { 관측 } \\
\text { 치수 }\end{array}$ & 평균 & 중간값 & $\begin{array}{l}\text { 관측 } \\
\text { 치수 }\end{array}$ & 평균 & 중간값 & $\begin{array}{c}\text { 평균 } \\
(2)-(5)\end{array}$ & $\begin{array}{l}\text { 중간값 } \\
(3)-(6)\end{array}$ \\
\hline & (1) & (2) & (3) & (4) & (5) & (6) & (7) & (8) \\
\hline $\mathrm{M} / \mathrm{B}$ equity & 408 & 0.654 & 0.452 & 1,088 & 1.919 & 1.169 & $-1.265^{* * *}$ & $-0.716^{\text {*** }}$ \\
\hline Eqt. Stake/Assets & 408 & 0.755 & 0.816 & 1,088 & 0.102 & 0.053 & $0.653^{* * *}$ & $0.763^{* * *}$ \\
\hline Div. Income/Sales & 408 & 0.177 & 0.212 & 1,088 & 0.004 & 0.000 & $0.173^{* * *}$ & $0.212^{* * *}$ \\
\hline $\log$ (Assets) & 408 & 27.887 & 27.711 & 1,088 & 26.922 & 26.875 & $0.964^{* * * *}$ & $0.836^{* * *}$ \\
\hline$\Delta \mathrm{PPE} / \mathrm{lag}$ Sales & 408 & 0.039 & 0.010 & 1,088 & 0.037 & 0.005 & 0.002 & 0.005 \\
\hline EBIT/Sales & 408 & 0.076 & 0.061 & 1,088 & 0.051 & 0.053 & $0.025^{* * *}$ & $0.008^{* * *}$ \\
\hline Leverage & 408 & 0.230 & 0.225 & 1,088 & 0.226 & 0.225 & 0.005 & 0.000 \\
\hline Volatility & 408 & 38.338 & 36.008 & 1,088 & 41.509 & 38.169 & $-3.170^{* * *}$ & $-2.162^{* * *}$ \\
\hline
\end{tabular}


The Holding Company Discount in Korea's Stock Market

〈표 5〉 지주회사 체제 기업집단: 지주회사 vs. 자- 손자회사(계속)

\begin{tabular}{|c|c|c|c|c|}
\hline & \multicolumn{4}{|c|}{ 종속변수: M/B equity } \\
\hline & (1) & $(2)$ & (3) & (4) \\
\hline \multicolumn{5}{|c|}{ 패널 B.1: Baseline 모형 } \\
\hline Holding Dummy & $\begin{array}{l}-1.023^{* * *} \\
(-5.69)\end{array}$ & & & $\begin{array}{l}-0.923 \\
(-1.49)\end{array}$ \\
\hline Eqt. Stake/Assets & & $\begin{array}{l}-1.401^{* * *} \\
(-5.17)\end{array}$ & & $\begin{array}{l}-0.454 \\
(-0.43)\end{array}$ \\
\hline Div. Income/Sales & & & $\begin{array}{l}-2.215^{* * *} \\
(-4.10)\end{array}$ & $\begin{array}{r}1.112 \\
(0.98) \\
\end{array}$ \\
\hline 통제변수 & Yes & Yes & Yes & Yes \\
\hline 연도고정효과 & Yes & Yes & Yes & Yes \\
\hline 관측치 수 & 1,496 & 1,496 & 1,496 & 1,496 \\
\hline Adj. $\mathrm{R}^{2}$ & 0.135 & 0.132 & 0.113 & 0.136 \\
\hline \multicolumn{5}{|c|}{ 패널 B.2: 기업집단고정효과 추가 } \\
\hline Holding Dummy & $\begin{array}{l}-0.565^{* * *} \\
(-3.45)\end{array}$ & & & $\begin{array}{l}-0.856 \\
(-0.90)\end{array}$ \\
\hline Eqt. Stake/Assets & & $\begin{array}{l}-0.702^{* *} \\
(-2.21)\end{array}$ & & $\begin{array}{l}-0.079 \\
(-0.05)\end{array}$ \\
\hline Div. Income/Sales & & & $\begin{array}{c}-0.535 \\
(-1.00)\end{array}$ & $\begin{array}{r}1.822 \\
(1.47)\end{array}$ \\
\hline 통제변수 & Yes & Yes & Yes & Yes \\
\hline 연도고정효과 & Yes & Yes & Yes & Yes \\
\hline 기업집단고정효과 & Yes & Yes & Yes & Yes \\
\hline 관측치 수 & 1,496 & 1,496 & 1,496 & 1,496 \\
\hline Adj. $R^{2}$ & 0.309 & 0.307 & 0.303 & 0.310 \\
\hline
\end{tabular}

소속 기업으로 표본을 한정할 경우 Eqt. Stake/Assets와 Div. Income/Sales가 해당 기업이 지주회사인가를 더 잘 반영하기 때문에 나타나는 결과로 해석된다. 한편 패널 B.1의 칼럼 (4)에서는 Holding Dummy의 계수값이 음의 값을 가지지만 유의성을 상실하는데, 이 결과는 회귀식에 설명변수로 함께 포함된 Eqt. Stake/Assets와 Div. Income/Sales가 해당 기업이 지주회사인지 여부를 더 잘 반영하기 때문에 Holding Dummy의 설명력을 감소시키기 것으로 보인다.

패널 B.2의 회귀식에서는 추가적으로 기업집단고정효과를 통제하였는데, 패널 B.1의 회귀식 결과와 대체적으로 비슷한 결과를 나타내고 있다. 칼럼 (1)의 Holding Dummy는 유의한 음의 계수값을 가지며, 칼럼 (2)와 (3)의 Eqt. Stake/Assets와 Div. Income/Sales는 음의 값을 가지는데, Div. Income/Sales는 유의성이 없다. 칼럼 (4)에서 세 설명변수를 동시에 넣었을 경우 Holding Dummy는 음의 계수값을 가지지만 유의성을 상실한다.

요약하자면, 지주회사는 자신이 지배하는 자·손자회사에 비해서도 상당히 저평가 되어 있다. 지주회사와는 달리 그들의 자·손회사들에게는 저평가 현상이 존재하지 않는 것으로 보인다. 지주회사 체제 기업집단 소속 기업으로 분석을 한정할 경우 계열사 보유지분 크기와 배당수입 크기 또한 기업가치 저평가 현상을 설명할 수 있는 능력이 있는 것으로 보인다. 
한국증권학회지 제48권 6호 (2019)

\section{4 기업 펀더멘탈 대비 지주회사의 저평가 분석}

이 절에서는 지주회사가 수익성, 성장성 등의 기업펀더멘탈에 비해서도 저평가 되어 있는가를 분석한다. 이를 위해 전체 표본(즉, 지주회사와 비지주회사가 모두 포함된 표본)에 대해 Campello and Graham(2013)의 회귀모형을 추정한 후 이 회귀모형의 추정오차를 지주회사 등의 집단 별로 분석한다.15) 이 방법론에서는 Campello and Graham(2013) 회귀식의 예측값(즉, 종속변수인 $\mathrm{M} / \mathrm{B}$ equity의 추정치)을 기업 펀더멘탈을 반영한 적정기업가치로 가정한다. 따라서 회귀식의 추정오차가 음(양)의 값을 가지면 실제기업가치가 적정기업가치보다 낮다(높다)는 의미이므로 해당 기업의 기업가치가 기업펀더멘탈 대비 저평가(고평가)되어 있다고 판단한다.

<표 6>에 보고된 지주회사의 추정오차 평균과 중간값은 모두 음의 값(-0.432와 -0.466$)$ 이며 통계적으로 유의한 크기이므로 지주회사의 기업가치가 펀더멘탈 대비 저평가 되어 있다는 해석이 가능하다. 반면 비지주회사와 지주회사의 자·손자회사의 경우는 추정오차의 평균이 모두 양의 값을 가지기 때문에 평균 기준으로는 기업가치가 펀더멘탈 대비 저평가 되어 있다고 볼 수 없다. 표의 아래 부분은 회귀식 추정오차의 집단 간 차이를 비교하는데, 평균 기준으로 지주회사는 비지주회사 및 자신의 자·손자회사 대비 유의적으로 더 큰 음의 예측오차 값을 나타내기 때문에 지주회사의 펀더멘탈 대비 저평가 현상은 다른 집단에 비해 유의적으로 큰 것으로 보인다. 한편 중간값 기준으로는 지주회사의 펀더멘탈 대비 저평가 현상이 비지주회사보다 더 크지는 않았다.

\section{〈표 6〉 펀더멘탈 대비 저평가 여부 분석}

표는 Campello and Graham(2013)의 회귀식의 추정오차-즉, '추정 M/B equity'와 '실제 M/B equity'값의 차이 - 를 지주회사, 비지주회사, 지주회사의 자·손자회사 별로 보고한다. Campello and Graham(2013) 회귀식의 추정결과는 <부록 3>에서 보고하였다. 표본은 2002 2017년 기간 상장기업을 대상으로 <부록 $1>$ 의 절차를 따라 완성하였다. '지주회사'는 공정거래상 지주회사이며 '비지주회사'는 지주회사를 제외한 회사이며 '지주회사의 자·손자회사'는 지주회사가 소속된 기업집단의 자회사와 손자회사이다. 변수의 정의는 <부록 $2>$ 에 제시되었다. 모든 연속변수는 분포의 상하위 각각 $1 \%$ 에서 윈저라이저하였다. 관측치 수는 기업연도 수를 의미한다. 평균과 중간값에 대한 차이 검증은 t-test와 Wilcoxon's Z-test이다. *, *****는 각각 $10 \%, 5 \%, 1 \%$ 수준의 양측검정 유의성을 의미한다.

\begin{tabular}{lcccc}
\hline & 관측치 수 & 평균 & 중간값 & 표준편차 \\
\hline 전체 기업 & 21,488 & 0.000 & $-0.876^{* * *}$ & 4.695 \\
지주회사 & 408 & $-0.432^{* * *}$ & $-0.466^{* * *}$ & 1.358 \\
비지주회사 & 21,080 & 0.008 & $-0.890^{* * *}$ & 4.737 \\
지주회사의 자·손회사 & 1,088 & $0.556^{* * *}$ & $0.108^{* * *}$ & 2.716 \\
\hline 지주회사-비지주회사 & & $-0.440^{* * *}$ & $0.424^{* * *}$ & \\
지주회사-지주회사의 자·손회사 & & $-0.988^{* * *}$ & $-0.574^{* * *}$ & \\
\hline
\end{tabular}

따라서 분석 결과는 지주회사는 펀더멘탈 대비 저평가 되어 있음을 시사하며 비지주회사와 자회사와 대비하여도 펀더멘탈 대비 저평가 되어 있는 정도가 유의하다는 증거도 존재한다.

15) 전체 표본기업에 대한 Campello and Graham(2013) 회귀모형 추정결과는 <부록 3>에 보고하였다. 
The Holding Company Discount in Korea's Stock Market

\section{5 사실상 지주회사의 기업가치 저평가 여부 분석}

한국주식시장의 상장회사 중에는 공정거래법에 따라 설립된 지주회사는 아니지만, 지주회사로 일컬어지는 회사가 다수 존재한다. 이 회사들은 자사의 고유 사업을 영위하면서 기업집단 계열사를 지배통제하는 역할을 하고 있는 사업지주회사들이다. 본 절에서는 이와 같은 사업지주회사들은 '사실상의 지주회사'라고 지칭하고 이들에게도 기업가치 저평가 현상이 존재하는가를 분석한다.

〈표 7〉사실상 지주회사, 지주회사 및 기타 회사의 기초통계량

표는 표본기업 중 '사실상 지주회사'를 골라 이들의 기업가치와 기업특성을 '지주회사'(즉, 공정거래법상 지주회사) 및 '기타 회사'(<표 1>의 비지주회사 중 사실상 지주회사를 제외한 나머지)와 비교한다. 표본은 2002 2017년 기간 상장기업을 대상으로 <부록 1>의 절차를 따라 완성하였다. 사실상 지주회사는 공정거래법상 지주회사 체제를 취하고 있지 않은 기업집단에 대해 소유지분구조도 상 가장 상위에 위치한 기업으로 정의되며 소유지분구조도는 공정거래위원회의 자료를 사용하였다. 변수의 정의는 <부록 $2>$ 에 제시되었다. 모든 연속변수는 분포의 상하위 각각 $1 \%$ 에서 윈저라이저하였다. 패널 $\mathrm{A}$ 는 사실상 지주회사, 지주회사, 기타 회사를 대상으로 회귀식에 사용되는 주요 변수들에 대한 기초통계량을 나타내며 관측치 수는 기업연도 수를 의미한다. 패널 $\mathrm{B}$ 에서는 각 변수들의 평균과 중간값에 대한 차이 검증(t-test 및 Wilcoxon's Z-test)을 보고한다. *, **, ***는 각각 $10 \%, 5 \%, 1 \%$ 수준의 양측검정 유의성을 의미한다. 패널 $\mathrm{A}$ : 기초통계량

\begin{tabular}{|c|c|c|c|c|c|c|c|c|c|}
\hline & \multicolumn{3}{|c|}{ 사실상 지주회사 } & \multicolumn{3}{|c|}{ 지주회사 } & \multicolumn{3}{|c|}{ 기타 회사 } \\
\hline & $\begin{array}{l}\text { 관측 } \\
\text { 치수 }\end{array}$ & 평균 & 중간값 & $\begin{array}{l}\text { 관측 } \\
\text { 치수 }\end{array}$ & 평균 & 중간값 & $\begin{array}{l}\text { 관측 } \\
\text { 치수 }\end{array}$ & 평균 & 중간값 \\
\hline & $(1)$ & (2) & (3) & $(4)$ & (5) & (6) & (7) & (8) & (9) \\
\hline $\mathrm{M} / \mathrm{B}$ equity & 264 & 2.530 & 1.016 & 408 & 0.654 & 0.452 & 20,816 & 2.350 & 0.951 \\
\hline Eqt. Stake/Assets & 264 & 0.198 & 0.161 & 408 & 0.755 & 0.816 & 20,816 & 0.104 & 0.043 \\
\hline Div. Income/Sales & 264 & 0.003 & 0.000 & 408 & 0.177 & 0.212 & 20,816 & 0.003 & 0.000 \\
\hline $\log ($ Assets $)$ & 264 & 29.728 & 29.894 & 408 & 27.887 & 27.711 & 20,816 & 25.601 & 25.366 \\
\hline$\Delta$ PPE/lag Sales & 264 & 0.031 & 0.012 & 408 & 0.039 & 0.010 & 20,816 & 0.035 & 0.004 \\
\hline EBIT/Sales & 264 & 0.085 & 0.059 & 408 & 0.076 & 0.061 & 20,816 & 0.005 & 0.041 \\
\hline Leverage & 264 & 0.297 & 0.307 & 408 & 0.230 & 0.225 & 20,816 & 0.225 & 0.205 \\
\hline Volatility & 264 & 42.448 & 39.748 & 408 & 38.338 & 36.008 & 20,816 & 54.561 & 51.378 \\
\hline
\end{tabular}

패널 $\mathrm{B}$ : 차이 검증

\begin{tabular}{|c|c|c|c|c|}
\hline & \multicolumn{2}{|c|}{ 사실상 지주회사-지주회사 } & \multicolumn{2}{|c|}{ 사실상 지주회사-기타 회사 } \\
\hline & 평균 (2)-(5) & 중간값 (3)-(6) & 평균 (2)-(8) & 중간값 (3)-(9) \\
\hline & $(10)$ & (11) & (12) & (13) \\
\hline M/B equity & $1.876^{* * *}$ & $0.563^{* * *}$ & 0.179 & 0.064 \\
\hline Eqt. Stake/Assets & $-0.557^{* * *}$ & $-0.655^{* * *}$ & $0.094^{* * *}$ & $0.118^{* * *}$ \\
\hline Div. Income/Sales & $-0.174^{* * *}$ & $-0.212^{* * *}$ & 0.001 & $0.000^{* * *}$ \\
\hline $\log$ (Assets) & $1.842^{* * *}$ & $2.182^{* * *}$ & $4.128^{* * *}$ & $4.527^{* * *}$ \\
\hline$\Delta \mathrm{PPE} / \mathrm{lag}$ Sales & -0.008 & 0.002 & -0.004 & $0.009^{* *}$ \\
\hline EBIT/Sales & 0.009 & -0.002 & $0.080^{* * *}$ & $0.018^{* * *}$ \\
\hline Leverage & $0.067^{* * *}$ & $0.083^{* * *}$ & $0.073^{* * *}$ & $0.103^{* * *}$ \\
\hline Volatility & $4.110^{* * *}$ & $3.741^{* * *}$ & $-12.113^{* * *}$ & $-11.630^{* * *}$ \\
\hline
\end{tabular}


한국증권학회지 제48권 6호 (2019)

<표 7>은 '사실상 지주회사'의 기업가치와 주요 기업특성의 평균과 중간값을 '지주회사'(즉, 공정거래법상 지주회사)와 '기타 회사'와 함께 보고한다. 표의 첫 행의 변수는 기업가치를 나타내는 $\mathrm{M} / \mathrm{B}$ equity인데, 사실상 지주회사의 $\mathrm{M} / \mathrm{B}$ equity의 평균과 중간값은 각각 2.530 과 1.016 으로 지주회사의 0.654와 0.452에 비해 상당히 높은 값을 나타내고 있으며 기타 회사의 2.350과 0.951보다 높다. 패널 $\mathrm{B}$ 의 유의성 분석 결과는 사실상 지주회사의 $\mathrm{M} / \mathrm{B}$ equity가 평균과 중간값 면에서 지주회사보다는 유의적으로 높으나 기타 회사에 비해서는 유의적으로 높지는 않음을 보고한다.

사실상 지주회사는 자사 고유사업을 영위하기 때문에 별도 자산에서 계열사 지분이 차지하는 비중과 별도 매출액에서 배당수입액이 차지하는 비중이 공정거래법상 지주회사보다 낮을 것으로 예상된다. 이 예상과 부합하게 사실상 지주회사의 계열사지분 크기(Eqt Stake/Assets)의 평균은 0.198 로 공정거래법상 지주회사의 평균값(0.755)보다는 상당히 낮다. 또한 사실상 지주회사의 배당수입 크기(Div. Income/Sales)의 평균은 0.003으로 공정거래법상 지주회사의 평균 0.177 에 비해 매우 낮다. 한편 사실상 지주회사는 공정거래법상 지주회사에 비해 연결기준 기업규모 $(\log$ (Assets)가 유의적으로 크고 부채비율(Leverage)이 유의적으로 높으며 주가수익률 변동성 (Volatility) 또한 유의적으로 크다.

<표 8>은 기업가치 회귀식에 '사실상 지주회사 더미'(De Facto Holding Dummy) 변수를 설명변수로 추가한 회귀분석 결과를 보고한다. De Facto Holding Dummy는 사실상 지주회사는 1 , 그 밖의 기업에는 0의 값을 부여하는 더미변수이다. 패널 $\mathrm{A}$ 의 칼럼 (1)은 De Facto Holding Dummy가 유의한 양의 계수값(1.736)을 나타내는 결과를 보고하며 이는 사실상의 지주회사가 다른 기업들에 비해 높은 기업가치를 가지고 있다는 것을 시사한다. 칼럼 (2)와 (3)은 Holding Dummy와 설명변수를 추가한 회귀분석결과를 보고 하는데, 마찬가지로 De Facto Holding Dummy가 유의한 양의 계수값(각각 1.716과 1.724)을 나타내어 사실상의 지주회사가 다른 기업들에 비해 높은 기업가치를 나타내는 현상을 확인해 주고 있다. 한편 칼럼 (3)에서 Holding Dummy는 음의 계수값을 나타내어 공정거래법상 지주회사들이 낮은 기업가치를 나타내는 현상을 재차 확인할 수 있다.

패널 $\mathrm{B}$ 는 기업가치 회귀식에 기업집단고정효과를 추가한 추정결과를 보고한다. 모든 칼럼 (1)-(3)에서 De Facto Holding Dummy는 양의 계수값을 나타낸다(각각 0.175, 0.162, 0.148). 하지만 패널 $\mathrm{A}$ 에서와는 달리 계수값의 통계적인 유의성은 없다. 따라서 패널 $\mathrm{A}$ 의 결과와 결합하여 해석하자면, 사실상의 지주회사는 다른 기업들에 비해 유의적으로 높은 기업가치를 가지지만 (패널 A의 결과), 자사가 소속된 기업집단 내 기업에 비해서는 유의적으로 높은 기업가치를 나타내지는 않는 것으로 보인다(패널 $\mathrm{B}$ 의 결과). 이는 사실상의 지주회사의 높은 기업가치는 자사가 소속된 기업집단의 높은 기업가치를 반영하고 있는 것이라 해석될 수도 있다. 어쨌든 패널 $\mathrm{A}$ 의 결과와 마찬가지로 패널 $\mathrm{B}$ 의 결과는 사실상의 지주회사 더미변수가 음의 계수 값을 가지지 않음을 보고하기 때문에 사실상의 지주회사에게는 기업가치 디스카운트 현상이 없다고 결론 내릴 수 있다. 
The Holding Company Discount in Korea's Stock Market

〈표 8〉기업가치 회귀분석: 사실상 지주회사 더미변수 포함

표는 사실상의 지주회사 더미를 주 설명변수로 사용한 기업가치 회귀분석 결과를 보고한다. 표본은 2002 2017년 기간 상장기업을 대상으로 <부록 $1>$ 의 절차를 따라 완성하였다. 종속변수는 기업가치 측정치인 $\mathrm{M} / \mathrm{B}$ equity(자기자본의 시장가치-장부가치 비율)이다. 사실상 지주회사 더미(De Facto Hold Dummy)는 사실상 지주회사는 1 , 그 밖의 기업에는 0 의 값을 부여한다. 사실상 지주회사는 공정거래법상 지주회사 체제를 취하고 있지 않은 기업집단에 대해 소유지분구조도 상 가장 상위에 위치한 기업으로 정의되며 소유지분구조도는 공정거래위원회의 자료를 사용하였다. Holding Dummy는 지주회사 더미변수 이며 공정거래법에 따라 설립된 지주회사의 경우에는 1 , 그 밖의 상장회사는 0 의 값을 가진다. 회귀식에 추가된 통제변수들은 $\log$ (Assets), $\Delta \mathrm{PPE} / \mathrm{lag}$ Sales, EBIT/Sales, Leverage, Volatility 이며 이들의 추정계수는 간결성을 위해 표에서 생략하였다. 변수의 정의는 <부록 $2>$ 에 제시되었다. 모든 연속변수는 분포의 상하위 각각 $1 \%$ 에서 윈저라이저하였다. 관측치 수는 기업연도 수를 의미한다. 괄호 안의 수치는 firm-clustered standard error를 사용한 t값이며 * ${ }^{* * *}{ }^{* * *}$ 는 각각 $10 \%, 5 \%, 1 \%$ 수준의 양측검정 유의성을 의미한다.

종속변수: $\mathrm{M} / \mathrm{B}$ equity

\begin{tabular}{|c|c|c|c|}
\hline & \multicolumn{3}{|c|}{ 종속변수: M/B equity } \\
\hline & (1) & (2) & (3) \\
\hline \multicolumn{4}{|l|}{ 패널 A: Baseline model } \\
\hline Holding Dummy & & $\begin{array}{l}-0.193 \\
(-1.22)\end{array}$ & $\begin{array}{l}-0.418^{*} \\
(-1.65)\end{array}$ \\
\hline De Facto Hold. Dummy & $\begin{array}{l}1.736^{* *} \\
(2.08)\end{array}$ & $\begin{array}{l}1.716^{* *} \\
(2.05)\end{array}$ & $\begin{array}{l}1.724^{* *} \\
(2.05)\end{array}$ \\
\hline Eqt. Stake/Assets & & & $\begin{array}{l}0.256 \\
(0.61)\end{array}$ \\
\hline Div. Income/Sales & & & $\begin{array}{l}0.444 \\
(0.63)\end{array}$ \\
\hline 통제변수 & Yes & Yes & Yes \\
\hline 연도고정효과 & Yes & Yes & Yes \\
\hline 관측치 수 & 21,488 & 21,488 & 21,488 \\
\hline Adj. $\mathrm{R}^{2}$ & 0.119 & 0.119 & 0.119 \\
\hline \multicolumn{4}{|c|}{ 패널 $\mathrm{B}$ : 기업집단고정효과 추가 } \\
\hline Holding Dummy & & $\begin{array}{l}-0.486^{* * *} \\
(-2.76)\end{array}$ & $\begin{array}{l}-0.880^{* * * *} \\
(-2.93)\end{array}$ \\
\hline De Facto Hold. Dummy & $\begin{array}{l}0.175 \\
(0.32)\end{array}$ & $\begin{array}{r}0.162 \\
(0.30)\end{array}$ & $\begin{array}{l}0.148 \\
(0.27)\end{array}$ \\
\hline Eqt. Stake/Assets & & & $\begin{array}{l}0.394 \\
(0.91)\end{array}$ \\
\hline Div. Income/Sales & & & $\begin{array}{l}0.766 \\
(0.98)\end{array}$ \\
\hline 통제변수 & Yes & Yes & Yes \\
\hline 연도고정효과 & Yes & Yes & Yes \\
\hline 기업집단고정효과 & Yes & Yes & Yes \\
\hline 관측치 수 & 21,488 & 21,488 & 21,488 \\
\hline Adj. $R^{2}$ & 0.124 & 0.124 & 0.124 \\
\hline
\end{tabular}


한국증권학회지 제48권 6호 (2019)

결론적으로 '공정거래법상 지주회사'와는 달리 '사실상 지주회사'는 기업가치가 저평가 되어 있지 않으며 오히려 고평가 되어 있는 증거도 있음을 알 수 있었다. 이는 한국주식시장의 투자자들이 자회사 통제관리를 주업으로 하는 순수지주회사에게는-자체 사업을 운영하는 사업지주회사에 비해-낮은 기업가치를 부여함을 의미한다.

\section{6 지주회사 디스카운트 원인 탐구}

실증분석을 통해 (공정거래법상) 지주회사는 다른 상장회사에 비해 저평가 되어 있는 반면 사실상의 지주회사에게는 저평가 현상이 존재하지 않음을 알게 되었다. 그렇다면 지주회사 디스카운트의 원인은 무엇일까? 저평가의 원인을 뚜렷하게 밝히기는 어렵지만, 주식의 가치는 투자자의 수요에 의해 결정됨에 비추어 투자자들이 지주회사 주식을 얼마나 매력 있는 대상으로 생각하는지 고려하고자 한다. 연구를 위해 주식의 거래회전율의 크기가 투자자의 주식에 대한 투자관심도를 반영한다고 가정하고, 지주회사는 비지주회사에 비해 거래회전율이 낮을 것이라고 예측한다. 또한 지주회사가 단독상장 되어 있는 경우-즉, 지주회사가 기업집단 소속 회사 중 유일한 상장회사인 경우-에 비해 자·손자회사와 함께 공동상장 되어 있는 경우 투자자들의 수요가 자·손자회사 쪽으로 집중되어 지주회사에 대한 투자자의 투자관심도가 낮은 것이라는 예측도 분석하고자 한다.

예측 1: 투자자들은 비지주회사에 비해 지주회사에 대해 낮은 투자관심을 나타낸다.

예측 2: 투자자들은 지주회사 단독상장에 비해 지주회사-자·손자회사 공동상장의 경우 지주회사에 대해 낮은 투자관심을 나타낸다.

<표 9>의 패널 A에서는 지주회사와 비지주회사의 거래회전율을 비교한다. 거래회전율(I)은 “거래량/상장주식수”를 거래일별로 계산한 후 연 평균값을 구한 것인데 지주회사의 평균과 중간값(0.004와 0.002)은 모두 비지주회사(0.019와 0.010)에 비해 $1 / 5$ 정도 수준이다. 거래회전율(II)은 연간 총거래량을 상장주식수로 나누어 구한 값인데, 지주회사의 평균과 중간값은 1.062 와 0.567 로 상장된 주식의 소유권 교체가 일어나는 횟수가 대략 1 년에 1 회 또는 그 이하임을 의미한다. 반면 비지주회사의 거래회전율(II) 평균과 중간값은 4.432와 2.275 로 소유권 교체가 빈번함을 시사한다. 이 관측들은 거래회전율로 측정한 투자자들의 투자관심도가 지주회사에 대해 현저히 낮음을 시사하며 따라서 지주회사를 매력적인 투자대상으로 간주하지 않는다는 예측 1 을 지지한다.16)

패널 $\mathrm{B}$ 에서는 공정거래법상 지주회사를 '지주회사 단독상장인 경우'와 '자·손자회사와 동시 상장되어 있는 경우’로 구분하여 분석한다. 기업집단 소속 회사 중 지주회사만 단독상장 되어

16) 거래회전율은 기업규모, 수익성, 성장성에 따라 달라질 수 있다. 표로 보고하지 않았지만, 저자들은 거래회전율을 종속변수로 하고 지주회사 더미변수를 주 설명변수로 $\log$ (Assets), $\Delta \mathrm{PPE} / \mathrm{lag}$ Sales, EBIT/Sales, Leverage, Volatility 그리고 연도고정효과를 통제한 회귀식을 추정하였다. 추정결과 지주회사 더미변수가 유의적인 음의 계수값을 나타내어 지주회사의 거래회전율이 비지주회사보다 낮은 현상을 확인할 수 있었다. 
The Holding Company Discount in Korea's Stock Market

있는 경우는 고유기업(기업연도) 6개(25개)에 불과한 반면, 지주회사와 함께 적어도 하나의 자회사와 공동상장되어 있는 경우는 고유기업(기업연도) 62개(383개)에 달해 지주회사는 적어도 하나의 자·손자회사와 공동상장되어 있는 경우가 대부분인 것으로 보인다. 단독상장의 경우는 적은 관측치 수로 인해 신뢰성 있는 통계적 추론이 어렵지만, 패널 $\mathrm{B}$ 에 보고된 수치에 따르면 단독상장 지주회사에게는 기업가치 디스카운트 현상이 존재하지 않거나 디스카운트의 규모가 작으며, 거래회전율이 공동상장 지주회사 대비 높다. 예를 들어 단독상장 지주회사의 $\mathrm{M} / \mathrm{B}$ equity의 평균과 중간값은 각각 1.347 과 0.926 으로 1 보다 높거나 1 에 근접하며 공동상장 지주회사의 M/B equity의 평균과 중간값(0.609와 0.406)보다 훨씬 높다. 또한 거래회전율도 단독상장 지주회사는 동시상장 지주회사에 비해 평균과 중간값이 두 배 정도 또는 그 이상 높다. 이는 동시상장의 경우 투자자의 수요가 사업자회사 쪽으로 집중되기 때문에 지주회사의 기업가치가 낮게 형성된다는 설명과 일관된 관측이며 예측 2 를 지지한다.

〈표 9〉지주회사에 대한 투자관심도

표는 주식 거래회전율 등의 변수를 보고한다. 표본은 2002 2017년 기간 상장기업을 대상으로 <부록 $1>$ 의 절차를 따라 완성하였다. 거래회전율(I)은 일별 거래량/상장주식수의 연평균값이며 거래회전율(II)은 연간 총거래량/상장주식수이다. 패널 $\mathrm{A}$ 는 전체 표본을 지주회사와 비지주회사로 나누어 비교하며 패널 $\mathrm{B}$ 는 공정거래법상 지주회사만을 대상으로 단독상장과 동시상장으로 구분해 비교한다. 단독상장이란 기업집단 소속 기업 중 지주회사만이 유일하게 상장된 경우이며 동시상장이란 지주회사가 적어도 하나의 자회사 또는 손자회사가 함께 상장된 경우이다. 모든 변수는 분포의 상하위 각각 $1 \%$ 에서 윈저라이저하였다. 관측치 수는 기업연도 수를 의미한다. 차이 검증은 평균과 중간값에 대한 차이 검증(t-test 및 Wilcoxon's Z-test)을 보고한다. ", ${ }^{* *},{ }^{* * *}$ 는 각각 $10 \%, 5 \%, 1 \%$ 수준의 양측검정 유의성을 의미한다.

패널 $\mathrm{A}$ : 전체 표본

\begin{tabular}{|c|c|c|c|c|c|c|c|c|}
\hline & \multicolumn{3}{|c|}{ (1) 지주회사 } & \multicolumn{3}{|c|}{ (2) 비지주회사 } & \multicolumn{2}{|c|}{ 차이검증 (1)-(2) } \\
\hline & 관측치 수 & 평균 & 중간값 & 관측치 수 & 평균 & 중간값 & 평균 & 중간값 \\
\hline$\overline{\mathrm{M} / \mathrm{B} \text { equ }}$ & 408 & 0.654 & 0.452 & 21,080 & 2.353 & 0.952 & $-1.699^{* * *}$ & $-0.500^{* * *}$ \\
\hline Volatility & 408 & 38.338 & 36.008 & 21,080 & 54.409 & 51.191 & $-16.071^{* * *}$ & $-15.183^{* * *}$ \\
\hline 거래회전율(I) & 408 & 0.004 & 0.002 & 21,080 & 0.019 & 0.010 & $-0.015^{* * *}$ & $-0.007^{* * *}$ \\
\hline 거래회전율(II) & 408 & 1.062 & 0.567 & 21,080 & 4.432 & 2.275 & $-3.370^{* * *}$ & $-1.709^{* * *}$ \\
\hline
\end{tabular}

패널 $\mathrm{B}$ : 지주회사

\begin{tabular}{|c|c|c|c|c|c|c|c|c|}
\hline & \multicolumn{3}{|c|}{ (1) 단독상장 } & \multicolumn{3}{|c|}{ (2) 동시상장 } & \multicolumn{2}{|c|}{ 차이검증 (1)-(2) } \\
\hline & 관측치 수 & 평균 & 중간값 & 관측치 수 & 평균 & 중간값 & 평균 & 중간값 \\
\hline / $\mathrm{B}$ & $25(6)$ & 1.347 & 0.926 & $383(62)$ & 0.609 & 0.406 & $0.738^{* * *}$ & $0.519^{* * *}$ \\
\hline Mat & $25(6)$ & 40.674 & 38.382 & 383(62) & 38.186 & 35.925 & 2.488 & 2.457 \\
\hline (I) & $25(6)$ & 0.009 & 0.006 & 383(62) & 0.004 & 0.002 & $0.005^{* * *}$ & $0.004^{* * *}$ \\
\hline 거래회전율(II) & $25(6)$ & 1.938 & 1.385 & 383(62) & 1.005 & 0.540 & $0.933^{* * *}$ & $0.845^{* * *}$ \\
\hline
\end{tabular}

\section{7 추가 분석}

\subsection{1 지주회사 전환 전과 후의 기업가치와 거래회전율 비교}

지금까지 실증분석은 지주회사와 다른 상장회사 간 비교에 초점을 맞추었기 때문에 지주회사의 기업가치가 전환 전에 비해 전환 후에 낮아지는 가에 대한 분석은 실시되지 않았다. <표 10>에서는 
한국증권학회지 제48권 6호 (2019)

표본에 포함된 지주회사(고유회사 68개)에 대해 전환 전과 후의 기업가치와 기업특성을 분석한다. 전환 전의 기업은 사업회사로 존재하고 있는 상태이므로 이 분석은 사업회사가 지주회사로 전환됨에 따라 기업가치가 하락하는가를 확인하는 의미가 있다.

<표 10>에 보고된 전환 전 M/B equity의 평균과 중간값(0.969와 0.645)은 모두 전환 후(0.654와 0.452)보다 유의적으로 높으며 이는 사업회사가 지주회사로 전환됨에 따라 기업가치가 하락하는 경향이 있음을 시사한다. 이 결과는 투자자들이 고유사업을 영위하지 않고 계열사 통제관리를 주목적으로 하는 지주회사의 가치를 낮게 평가한다는 결론과 일관된 것이다. 또한 <표 $10>$ 은 거래회전율이 평균과 중간값 모두 전환 전에 비해 전환 후에 현저하게 낮아지는 경향을 보고하는데, 예를 들어 거래회전율(II)의 평균은 전환 전 3.535 에서 전환 후 1.062 로 급격하게 하락한다. 이는 투자자의 투자관심이 지주회사 전환 후에 현저히 낮아짐을 시사한다.

\section{〈표 10〉 지주회사 전환 전과 후 비교}

표는 지주회사 전환 전과 후를 비교분석한다. 분석기간은 2002 2017년이다. 공정거래위원회 웹사이트에 공시된 각 지주회사의 설립년도를 사용하여 설립 직전년도까지의 기간은 “지주회사 전환 전(Before)"으로 설립년도를 제외한 이후 기간은 “지주회사 전환 후(After)"로 구분하였다. 연구표본에 포함된 공정거래법상 지주회사(고유기업 68개, 기업연도 408)를 대상으로 설립년도 이전 기간에 동일한 기업코드를 갖는 기업을 FnGuide에서 식별한 결과 고유기업 55개(기업연도 464개)를 찾을 수 있었으며 이들의 기업연도를 지주회사 전환 전(Before)으로 분류하였다. 모든 변수는 분포의 상하위 각각 $1 \%$ 에서 윈저라이저하였다. 관측치 수는 기업연도 수를 의미한다. 차이 검증은 평균과 중간값에 대한 차이 검증(t-test 및 Wilcoxon's Z-test)을 보고한다. *, ${ }^{* *},{ }^{* *}$ 는 각각 $10 \%, 5 \%, 1 \%$ 수준의 양측검정 유의성을 의미한다.

\begin{tabular}{|c|c|c|c|c|c|c|c|c|}
\hline & \multicolumn{3}{|c|}{ (1) 지주회사 전환 전 (Before) } & \multicolumn{3}{|c|}{ (2) 지주회사 전환 후 (After) } & \multicolumn{2}{|c|}{ 차이검증 (1) - (2) } \\
\hline & 관측치 수 & 평균 & 중간값 & 관측치 수 & 평균 & 중간값 & 평균 & 중간값 \\
\hline M/B equity & 464 & 0.969 & 0.645 & 408 & 0.654 & 0.452 & $0.315^{* * *}$ & $0.193^{* * * *}$ \\
\hline Eqt. stake/Assets & 464 & 0.154 & 0.111 & 408 & 0.755 & 0.816 & $-0.601^{* * *}$ & $-0.705^{* * *}$ \\
\hline Div. Income/Sales & 464 & 0.007 & 0.000 & 408 & 0.177 & 0.212 & $-0.170^{* * *}$ & $-0.212^{* * *}$ \\
\hline $\log$ (Assets) & 464 & 26.550 & 26.523 & 408 & 27.887 & 27.711 & $-1.336^{* * *}$ & $-1.188^{* * *}$ \\
\hline$\Delta \mathrm{PPE} / \mathrm{lag}$ Sales & 464 & 0.049 & 0.022 & 408 & 0.039 & 0.010 & 0.010 & $0.012^{* * *}$ \\
\hline EBIT/Sales & 464 & 0.073 & 0.066 & 408 & 0.076 & 0.061 & -0.003 & 0.006 \\
\hline Leverage & 464 & 0.257 & 0.268 & 408 & 0.230 & 0.225 & $0.026^{* *}$ & $0.043^{* *}$ \\
\hline Volatility & 464 & 52.483 & 49.903 & 408 & 38.338 & 36.008 & $14.145^{* * *}$ & $13.896^{* * *}$ \\
\hline 거래회전율(I) & 424 & 0.015 & 0.010 & 408 & 0.004 & 0.002 & $0.011^{* * *}$ & $0.007^{* * *}$ \\
\hline 거래회전율(II) & 424 & 3.535 & 2.268 & 408 & 1.062 & 0.567 & $2.473^{* * *}$ & $1.701^{* * *}$ \\
\hline
\end{tabular}

\subsubsection{Fama and French(1998) 기업가치 회귀식 추정}

기업재무 분야에서 자주 사용되는 기업가치 회귀분석 모형 중에는 Fama and French(1998) 모형이 있다.17) 이 모형은 Tobin's Q를 기업가치 측정치(즉, 종속변수)로 사용하며, 다양한 기업특성을 설명변수로 사용하는데 가장 큰 특징으로는 Tobin's Q의 미래값(2년 후 값)을 통제변수로 포함한다는 것이다. 본 연구자들은 Fama and French(1998) 회귀식을 따라 Tobin's $\mathrm{Q}$ 를 종속변수로 설정하고 지주회사 더미변수를 주된 설명변수로 추가한 후 전체표본에 대해

17) Bates et al.(2009), Kim et al.(2018) 등이 이 가치평가 모형을 사용하였다. 
The Holding Company Discount in Korea's Stock Market

추정한 결과 지주회사 더미변수가 여전히 유의적인 음의 값을 나타냄을 발견하였다.18) 이는 지주회사 디스카운트 현상이 다양한 기업가치 회귀모형에서 일관되게 발생함을 시사한다. 또한 본 연구는 기업가치 측정치로 사용하는 $\mathrm{M} / \mathrm{B}$ equity를 측정함에 있어 연결재무제표의 자본총계를 분모로 사용하였으나, 별도재무제표의 자본총계를 분모로 사용하여도 지주회사 디스카운트의 유의성은 유지되었다. 또한 연결재무제표의 자본총계 중 비지배지분을 차감하여 분모로 사용 하여도 지주회사 디스카운트의 유의성은 유지되었다.

한편 기업가치 변수로써 배당수익률(dividend yield)을 대체적인 변수로 고려할 수 있지만 배당수익률은 배당을 하지 않는 상당수의 기업을 표본에서 제외해야 하는 단점이 있다. 또한 비지주회사에 비해 지주회사는 평균적으로 배당규모가 높기 때문에 배당수익률을 기업가치 변수로 사용할 경우 지주회사 디스카운트 현상이 더욱 강화되어 보이는 결과가 초래된다.

\subsection{3 내생성 등 여러 강건성 점검}

표로 보고하진 않았으나 내생성 통제를 위해 propensity score matching(PSM)을 사용하여 분석하였지만 지주회사 디스카운트는 여전히 유의하였다.19) 구체적으로 <표 $3>$ 기업가치회귀식의 통제변수들을 사용하여 추정한 지주회사 확률을 바탕으로 매칭 통제집단을 구축하여 지주회사 집단과 비교하였으나 지주회사집단은 여전히 유의적으로 낮은 기업가치를 나타내었다. 한편 자기선택(self-selection)을 통제하는 수단으로 자주 사용되는 Heckman-2-step 방법은 본 연구에 적용하기에는 Before 기업(즉, 사업회사)과 After 기업(즉, 지주회사) 간에는 기업 성격 면에서 연속성이 없기 때문에 무리가 있어 사용하지 않았다.20) 또한 대리인비용을 통제하는 방편으로 가족기업인지 여부를 통제하였으며, 지배지분-현금흐름 괴리도를 통제하고 분석하였으나 지주회사 디스카운트는 여전히 유의하였다.

\section{8 토론}

\subsection{1 기업지배구조 또는 대리인비용이 지주회사 디스카운트의 원인인가?}

이 질문에 대한 대답이 Yes로 성립하기 위해서는 지주회사가 다른 상장기업에 비해 더 심한 기업지배구조 문제 또는 터널링 등의 대리인 문제를 나타낸다는 이론적 또는 실증적 증거가 있어야 한다. 다수의 선행연구가 기업지배구조의 후진성 또는 대리인 문제가 기업가치를 낮추는 효과가 있음을 시사한다.21) 하지만 공정거래법상 지주회사 체제는 투명성 등 지배구조를 선진화할

18) 이 회귀결과를 표로 보고하지 않았으나 독자의 요청이 있을시 제시할 수 있다.

19) 물론 Shipman et al.(2017)이 지적하였듯이 PSM은 내생성 또는 자기선택(self selection)을 통제하는 목적 보다는 functional form misspecification 문제를 완화하기 위해서 목적이 크다고 볼 수 있다.

20) 구체적으로 인적·물적 분할 또는 주식의 포괄적 이전을 통해 지주회사가 설립될 경우 사업회사 $\Rightarrow$ 지주회사+사업자회사의 과정을 거치는데, 지주회사는 자기사업이 없거나 미미하여 -즉, 이전에 존재하지 않던 회사가 설립되는 것이라 이해할 수 있어-지주회사의 before가 사업회사라고 보기에는 무리가 있다. 이에 따라 Heckman-2-step 방법의 1단계 choice regression에서 추정된 잔차(또는 Heckman lambda)를 2단계 valuation regression의 지주회사에 대해 부여하는 것은 논리적으로 무리가 있다.

21) Claessens et al.(2000), Bae et al.(2002), Baek et al.(2004) 등이 그 예이다. 
한국증권학회지 제48권 6호 (2019)

목적으로 도입된 제도이며 도입 목적이 어느 정도 달성되고 있다고 가정한다면, 지주회사 체제 소속 기업(지주회사 포함)은 다른 상장기업에 비해 지배구조·대리인 문제가 덜 심각할 것으로 추측된다. 이 경우 기업지배구조 또는 대리인문제가 지주회사 디스카운트의 원인일 가능성은 낮을 것이다.

기업집단 분석 시 대리인비용의 대용변수로 흔히 사용되는 변수는 지배-소유 괴리도(controlownership disparity)이다. 표로 보고하지는 않았지만, 본 연구자들은 대규모 기업집단 중 지주회사 체제를 취하고 있는 기업집단 소속 기업에 대해 지배-소유 괴리도를 측정한 결과, 지주회사의 괴리도가 자·손자회사에 비해 유의적으로 낮았다.22) 또한 터널링 등의 대리인 문제는 투자와 자금조달이 활발한 사업회사에서 발생할 가능성이 높은데, 평균적으로 지주회사는 사업회사인 자·손자회사에 비해 (별도재무제표 기준으로) 투자와 자금조달의 규모가 작다. 이 관측 또한 위 추측을 부정적으로 판단케 한다.

\subsection{2 지주회사에 대한 여러 법률적 행위 제한이 지주회사 디스카운트를 초래하는가?}

공정거래법은 지주회사에 대해 (자기자본 대비) 부채비율 $200 \%$ 이하, 자회사 최소 보유지분율 $20 \%$ 및 자회사 외의 국내회사 주식취득 제한 등의 규제를 두고 있다. 이 행위 제한은 지주회사의 성장기회를 제한하는 효과가 있기 때문에 이에 따라 지주회사 디스카운트가 발생할 가능성은 물론 있다. 하지만, 이 가능성이 그다지 크지 않음을 시사하는 증거들도 있다. 먼저 지주회사의 실제 부채비율은 <표 1>에 보고된 바와 같이 평균값과 중간값이 제한치인 $200 \%$ 보다 훨씬 낮은 수준에 형성되어 있어 지주회사의 행위를 실제로 제한하고 있는지 의문이다.23) 또한<표 $2>$ 에서 보고된 바와 같이 상장기업의 주식보유지분과 기업가치 간에는 음의 상관관계가 존재하기 때문에 적극적인 주식취득이 오히려 기업가치를 감소시킬 가능성도 있다. 따라서 지주회사에 대해 부여된 주식취득 제한이 지주회사 디스카운트를 초래하는가는 의문시 된다.

\subsection{3 지주회사 자산 대부분이 지분자산이기 때문에 디스카운트가 발생하는가?}

지주회사 디스카운트에 대한 설명으로 검토할 수 있는 주장 중 하나는 "지주회사가 보유하고 있는 자회사 지분자산은 투자수익률이 떨어지는 음(-)의 NPV 투자이며 이에 따라 기업가치가 낮다"는 것이다. Almeida et al.(2011) 등의 연구가 계열사지분과 기업가치 간 음(-)의 관계를 시사하는 증거를 보고한 바 있어 지주회사 디스카운트의 상당 부분이 이 원인에서 발생할 가능성이 높다.

본 연구는 이 가능성을 부정하지 않는다. 하지만, <표 3>과 <표 4>에서 보고되었듯이 전체 표본에 대한 회귀분석 결과는 지분자산의 크기(Eqt. Stake/Assets)가 기업가치에 미치는 영향이 유의적이지 않음을 보고하고 있다. 이는 지주회사 더미가 유의적인 음(-)의 영향을 나타내는 것과 대비된다. 따라서 지주회사 디스카운트는 단순히 지분자산이 크다는 이유 이외의 다른

22) 이 결과는 지배주주가 자·손자회사에 비해 지주회사에 많은 지분을 보유하고 있기 때문인 것으로 보인다. 한편 이 괴리도 계산은 $\mathrm{Kim}$ et al.(2007)의 방법을 따랐다.

23 ) 자기자본 대비 부채비율 200\%는 총자산 대비 부채비율로 전환할 경우 0.666 에 해당하는데, <표 $1>$ 에 보고된 지주회사의 평균과 중간값은 각각 0.230 과 0.225 로 이보다 훨씬 낮은 수준이다. 
The Holding Company Discount in Korea's Stock Market

원인도 있다고 판단된다. 또한 아래에 서술하듯이 일본의 순수지주회사는 자회사 지분을 자산 대비 50\% 이상 보유하고 있는데도 불구하고 디스카운트가 발생하지 않는 것으로 보인다. 따라서 위 주장의 설득력 확보를 위해서는 일본 지주회사와는 달리 한국 지주회사의 지분자산이 유달리 음(-)의 NPV 투자라는 증거가 필요할 것이다.

\subsection{4 지주회사 디스카운트는 한국 특유의 현상인가?}

일본에서는 2000년대부터 순수지주회사(별도 총자산 중 계열사 지분의 비중이 $50 \%$ 이상인 기업으로 정의)의 수가 꾸준히 증가해 왔기 때문에 일본의 지주회사에서도 한국의 지주회사와 유사한 디스카운트 현상이 발생하는지 분석할 수 있다. 하지만 앞서 서술하였듯이 일본의 학술지 게재 논문 중에는 이 주제를 다룬 논문이 없으며 미게재 논문 중 Kim et al.(2019)이 이 주제를 분석하였다. 이 저자들은 2002 2017년 기간을 대상으로 상장기업 중 비금융 순수지주회사 125 개를 선정한 후 기업규모로 매칭한 사업모회사(고유사업을 영위하는 모회사)들과 비교한다. 분석 결과 순수지주회사의 자기자본 시장가치-장부가치 비율(본 연구의 $\mathrm{M} / \mathrm{B}$ equity와 동일)의 평균은 사업모회사들에 비해 유의하게 높게 나타났기 때문에 일본의 경우는 지주회사 디스카운트 현상이 없는 것으로 보인다. 더구나 표본 순수지주회사의 $\mathrm{M} / \mathrm{B}$ equity의 평균과 중간값이 모두 1 을 훨씬 넘기 때문에 한국의 지주회사와는 달리 높은 기업가치를 보이는 것으로 판단된다. 한.일 지주회사 간의 대조적 현상의 원인은 파악하기 힘들지만, 한국의 지주회사 디스카운트 현상이 한국 특유의 현상일 가능성을 시사한다.

한편 앞서 서술한 바와 같이 미국의 경우 순수지주회사의 예는 사실상 없는 것으로 보인다. 그런데 KKR, Blackstone, Apollo Global Management, Carlyle Group 등의 인수합병 전문 투자회사(private equity fund)를 순수지주회사라고-다소 무리하지만-가정해 볼 때, 위 회사들은 상장되어 있기 때문에 이들의 자기자본 시장가치-장부가치 비율(M/B equity)을 계산할 수 있다. ${ }^{24)}$ 논문 작성 현재 finance.yahoo.com에서 구한 M/B equity의 값은 KKR 1.58, Blackstone 4.84, Apollo Global Management 9.41 Carlyle Group 3.83으로 모두 1보다 훨씬 높은 값을 나타내고 있다. 이는 한국 공정거래법상 지주회사가 1 보다 훨씬 낮은 $\mathrm{M} / \mathrm{B}$ equity값을 가지는 것과 대조되는 현상이다. 따라서 이 투자회사들에게는 디스카운트 현상이 있는 것으로 보이지는 않는다.

\subsection{5 투자자 관심도가 저조하면 기업가치가 낮아지는가?}

앞서 분석에서 지주회사 주식의 거래회전율이 타 주식에 비해 상당히 낮으며 지주회사 전환 후에 이 거래회전율이 급격히 하락하는 관측 등을 근거로 투자자들이 지주회사를 매력적인 투자대상으로 생각하지 않는다고 추론하였다. 그런데 저조한 투자자 관심도와 낮은 기업가치 간에 인과관계가 존재하는지에 대해서는 관련 선행연구가 없으며 실증하기가 쉽지 않다. 본 연구저자들은 (표로 보고하지는 않았지만) 전체 표본에 대해 M/B equity와 거래회전율 간의 관계를 분석하였는데, 두 변수 간에는 유의적인 음(-)의 상관관계가 있으며, 기업규모, 성장성,

24) 이 주식들의 주가 움직임에 대한 미디어의 관심은 "Value of Blackstone portfolio grows by 9.5\%"(Wall Street Journal 2018.7.20.) 등의 기사를 참고할 수 있다. 
한국증권학회지 제48권 6호 (2019)

수익성 등을 통제한 회귀식을 추정하여 거래회전율이 $\mathrm{M} / \mathrm{B}$ equity에 유의적인 음(-)의 영향을 미친다는 결과를 얻을 수 있었다. 하지만 두 변수 간의 유의성 있는 통계적 관계가 인과관계를 의미한다고 확정적으로 말할 수는 없다. 따라서 낮은 투자자 관심이 지주회사 디스카운트를 초래한다는 설명은 실증된 것은 아니기 때문에, 가능성 높은 추측으로 간주 되어야 할 것이다.

또한 투자자 관심도를 나타내는 대용변수로 주식 거래회전율이 아닌 대체적인 변수를 고려해 볼 필요가 있다.25) 참고할 수 있는 선행연구가 많지 않으나 Lee and Ahn(2018)은 소액주주의 수를 기업인지도를 나타내는 변수로 사용한 바 있다.26) 본 연구저자들은 Lee and Ahn(2018)을 따라 FnGuide에서 구한 소액주주(1\% 미만 지분 보유 주주로 정의) 수에 로그값을 취해 이를 투자자 관심도의 대용변수로 사용해 보았다. 그런데 소액주주 수는 기업규모와 양(+)의 관계를 가지는 등 기업특성에 따라 달라질 수 있다. 따라서 (표로 보고하지는 않았지만) 기업규모, 성장성, 수익성 등의 기업특성을 통제한 후 소액주주 수의 로그값을 종속변수로 설정한 회귀식을 추정한 결과, 주 설명변수인 지주회사 더미의 계수가 유의적인 음(-)의 값을 나타내었다. 이는 지주회사에 대한 투자자의 관심이 소액주주 수로 측정할 경우에도 비지주회사에 비해 유의적으로 낮음을 시사한다.

\section{5. 결어: 논문의 한계와 향후 연구}

본 연구는 종합적이고 엄밀한 분석을 통해 지주회사 디스카운트 현상을 확인하였으며, 이 디스카운트 현상이 그들의 자·손자회사나 사실상의 지주회사에는 발생하지 않아 (공정거래법상) 지주회사에만 나타나는 현상임을 보고하였다. 또한 지주회사 디스카운트를 초래하는 원인을 찾기 위해 지주회사에 대한 투자자의 관심이 저조한 증거를 제시하였으며, 투자자의 수요가 지주회사보다는 동시 상장된 자·손자회사 쪽으로 집중된다는 설명을 제시하였다.

하지만 본 연구의 한계로써 투자자의 저조한 관심이 기업가치 저평가를 초래하는지-즉 인과관계가 있는지-에 대한 설득력 있는 증거 제시는 없었음을 지적할 수 있다. 또한 본 연구는 지주회사에 대한 투자자의 관심이 저조한 이유를 뚜렷이 밝히지 못한 한계가 있다.27) 추측컨대 한국시장의 투자자들은 사업자회사처럼 주식수익률의 변동성이 높은 pure-play 주식을 선호하는 경향이 높고 매출과 수익의 변동성이 안정적이어서 상승잠재력이 상대적으로 낮은 지주회사는

25) 한편 거래회전율은 유동성을 나타내는 척도이기 때문에 Amihud(2002)의 비유동성 측정치와 개념적으로 관련이 있다. 그런데 Amihud(2002) 측정치의 분자는 주식수익률의 절대값이기 때문에 주가변동성(Volatility)이 작은 지주회사의 경우는-비주지회사에 비해-Amihud 측정치 값이 낮아 결과적으로 유동성이 높아 보이게 되는 편의(bias)가 있다고 판단된다. 이 이유 때문에 본 연구에서는 Amihud 측정치를 투자관심도 대용변수로 고려하지 않았다.

26) 이와 비슷하게 Lou(2014)는 소매투자자(retail investor)의 크기를 기업인지도를 나타내는 변수로 사용한 바 있다.

27) 또한 투자관심도에 대한 국내외 선행연구가 거의 없기 때문에 참고할 수 있는 객관적 대용치가 부재하다. 따라서 본 연구가 대용치로 사용한 거래회전율에 대해 주관적인 선택이라는 비판이 있을 수 있다. 
The Holding Company Discount in Korea's Stock Market

피하는 것으로 보인다. 한편 본 연구는 지주회사의 주식가치에 초점을 맞추어 디스카운트 현상을 탐구하였지만, 지주회사가 채권시장에서도 신용등급 면에서 디스카운트 되고 있다는 일화성 증거들이 제시되고 있어 향후 그 관련성을 탐구할 필요가 있다.28) 또한 본 연구는 기업가치 분석이 목적이므로 비상장기업은-기업가치를 객관적으로 얻을 수 없어-연구 대상에서 제외 하였지만, 지주회사 중 비상장회사의 비중이 상당히 높은 편이기 때문에, 기업집단이 지주회사를 상장 vs. 비상장으로 선택하는 동기 등에 대한 연구가 필요한 것으로 보인다.

일본 순수지주회사에 대한 최근 연구(Kim et al., 2019)에 따르면 일본의 순수지주회사에게는 디스카운트 현상이 존재하지 않기 때문에, 순수지주회사라고 볼 수 있는 한국의 공정거래법상 지주회사에게만 대조적으로 디스카운트 현상이 발생하는지 의문이 아닐 수 없다. 이에 대해 한.일 지주회사 간 비교 등의 후속 연구가 필요한 것으로 보인다. 또한 지주회사(또는 지주회사 체제 기업집단)에 대한 기업재무 분야의 연구 관심이 현재까지는 다소 저조한 상황인 것으로 보여지며 향후 지주회사의 투자·재무활동 등에 대한 학자들의 연구 성과를 기대해 본다.

28) “한일홀딩스, 신용등급 지주사 디스카운트 없다(더벨 2019년 7월 2일 기사)"를 참고 할 수 있다. 
한국증권학회지 제48권 6호 (2019)

\section{References}

Almeida, H., S. Y. Park, M. G. Subrahmanyam, and D. Wolfenzon, 2011, The Structure and Formation of Business Groups: Evidence from Korean Chaebols, Journal of Financial Economics, Vol. 99, pp. 447-475.

Amihud, Y., 2002, Illiquidity and Stock Returns: Cross-Sectional and Time-Series Effects, Journal of Financial Markets, Vol. 5, pp. 31-56.

Bae, K., J. Kang, and J. Kim, 2002, Tunneling or Valued Added? Evidence from Mergers by Korean Business Groups: Evidence from Mergers by Korean Business Groups, Journal of Finance, Vol. 57, pp. 2695-2740.

Baek, J., J. Kang, and K. Park, 2004, Corporate Governance and Firm Value: Evidence form the Korean Financial Crisis, Journal of Financial Economics, Vol. 71, pp. 265-313.

Baek, J., and J. Park, 2010, Information Effect of Holding Company on Shareholder Wealth and Credit Rating, Korean Journal of Business Administration, Vol. 23 (5), pp. 2377-2397.

Bates, T. W., K. M. Kahle, and R. M. Stultz, 2009, Why do U.S. Firms Hold So Much Cash than They Used To? Journal of Finance, Vol. 64, pp. 1985-2021.

Berger, P., and E. Ofek, 1995, Diversification's Effect on Firm Value, Journal of Financial Economics, Vol. 37, pp. 39-65.

Campello, M., and J. R. Graham, 2013, Do Stock Prices Influence Corporate Decisions? Evidence from the Technology Bubble, Journal of Financial Economics, Vol. 107, pp. 89-110.

Chay, J. B., H. Kim, and J. Suh, 2015, Firm age and Valuation: Evidence from Korea, Asia-Pacific Journal of Financial Economics, Vol. 44, pp. 721-761.

Choi, S., 2000, The Role of Holding Company as a Value Creator, LG Economic Research Institute, 2000-10-25, pp. 8-12.

Choi, S., and M. Lim, 2009, Corporate Governance and Earnings Management of Holding Company, Korean Accounting Journal, Vol. 18 (4), pp. 207-239.

Claessens, S., S. Djankov, and L. H. P. Lang, 2000, The Separation of Ownership and Control in East Asian Corporations, Journal of Financial Economics, Vol. 58, pp. 81-112.

Fama, E. F., and K. R. French, 1998, Taxes, Financing Decision, and Firm Value, Journal of Financial Economics, Vol. 53, pp. 819-843.

Fama, E. F., and K. R. French, 2015, A Five-Factor Asset-Pricing Model, Journal of Financial Economics, Vol. 116, pp. 1-22.

Gam, D., 2002, Implications for Holding Company Discount, LG Economic Research Institute, 2002-09-25, pp. 31-35.

Jung, D., 2008, The Comparison of the Performance, Firm Value, and Corporate Governance between Holding Company and Companies Group, Korean Journal of Business Administration, Vol. 21 (2), pp. 767-789. 
The Holding Company Discount in Korea's Stock Market

Kim, Y., S. Jang, J. Kang, and G. Lee, 2014, Transformation into Holding Company and Firm Value, Working Paper, pp. 608-624.

Kim, W., Y. Lim, and T. Sung, 2007, Group Control Motive as a Determinant of Ownership Structure in Business Conglomerates: Evidence from Korea's Chaebols, Pacific-Basic Finance Journal, Vol. 15, pp. 213-252.

Kim, S., S. Park, and J. Suh, 2018, A J-Shaped Cross-Sectional Relation between Dividends and Firm Value, Journal of Corporate Finance, Vol. 48, pp. 857-877.

Kim, J. H., H. H. Shin, and J. M. Goh, 2009, Transformation into Holding Company and Earnings Management, Accounting Information Review, Vol. 27 (4), pp. 147-180.

Kim, H., J. Suh, K. Uchida, and Y. Yasuda, 2019, Japan's Pure Holding Companies: Firm Value, Investment and Financing, mimeo, Hitotsubashi University.

Ko, D., 2008, Regulations for the Korean Holding Companies to Promote Corporate Restructuring, Korea Institute for Industrial Economics \& Trade, Issue Paper 2008-238, pp. 1-74.

Kwak, S. H., and S. B. Choi, 2008, The Effects of Holding Company on the Performance and Value of Its Affiliations: An Empirical Analysis, Journal of Regulation Studies, Vol. 17 (2), pp. 97-131.

Lee, E., 2014, Analysis of Profit Structure for Holding Companies, Economic Reform Research Institute, Issue \& Analysis, Vol. 5, pp. 1-20.

Lee, H. C., and H. Ahn, 2018, Advertising Expenditures, Number of Shareholders, and Stock Liquidity, Korean Journal of Financial Studies, Vol. 47 (4), pp. 607-633.

Lee, C., A. Shleifer, and R. H. Thaler, 1990, Anomalies: Closed-End Mutual Funds, Journal of Economic Perspective, Vol. 4, pp. 135-164.

Lou, D., 2014, Attracting Investor Attention through Advertising, Review of Financial Studies, Vol. 27, pp. 1797-1829.

Mansi, S., and D. Reeb, 2002, Corporate Diversification: What Gets Discounted, Journal of Finance, Vol. 57, pp. 2167-2183.

Pástor, L., and P. Veronesi, 2003, Stock Valuation and Learning about Profitability, Journal of Finance, Vol. 58, pp. 1749-1789.

Ra, C., and Y. Koh, 2009, The Financial Influence of Holding Company, Journal of Industrial Economics and Business, Vol. 22 (5), pp. 2231-2248.

Shimotani, M., 2012, Japanese Holding Companies: Past and Present, Japanese Research in Business History, Vol. 29, pp. 11-28.

Shin, H., J. Park, and Y. Kim, 2018, Holding Company and it's Firm Value, Korea Economic Research Institute, 2018-05, pp. 1-44.

Shipman, J. E., Q. T. Swanquist, and R. L. Whited, 2017, Propensity Score Matching, Accounting Review, Vol. 92, pp. 213-244.

山田和延, 2014, 日本企業のグループ経營の課題と對応, KPMG Insight, Vol. 8, pp. 1-8. 


\section{〈부록 1〉연구 표본}

패널 $\mathrm{A}$ 는 최종 표본 구축 과정을 상세하게 보고한다. 지주회사는 공정거래법상 지주회사를 의미하며 공정거래위원회 웹사이트(www.ftc.go.kr)의 지주회사 리스트를 이용해 선정하였다. 비지주회사는 지주 회사를 제외한 그 밖의 상장회사를 의미한다. 패널 $\mathrm{B}$ 는 표본의 연도별 분포를 보고하며 패널 $\mathrm{C}$ 는 표본에 포함된 지주회사의 산업별 분포를 보고한다. 패널 $\mathrm{D}$ 는 공정거래법상 지주회사를 택하고 있는 지주회사가 속한 기업집단 소속 기업을 지주회사, 자회사, 손자회사로 구분해 분포를 보고한다. 패널 $\mathrm{E}$ 는 사실상의 지주회사로 선정된 기업의 리스트를 보고한다.

패널 $\mathrm{A}$ : 표본 구축 과정

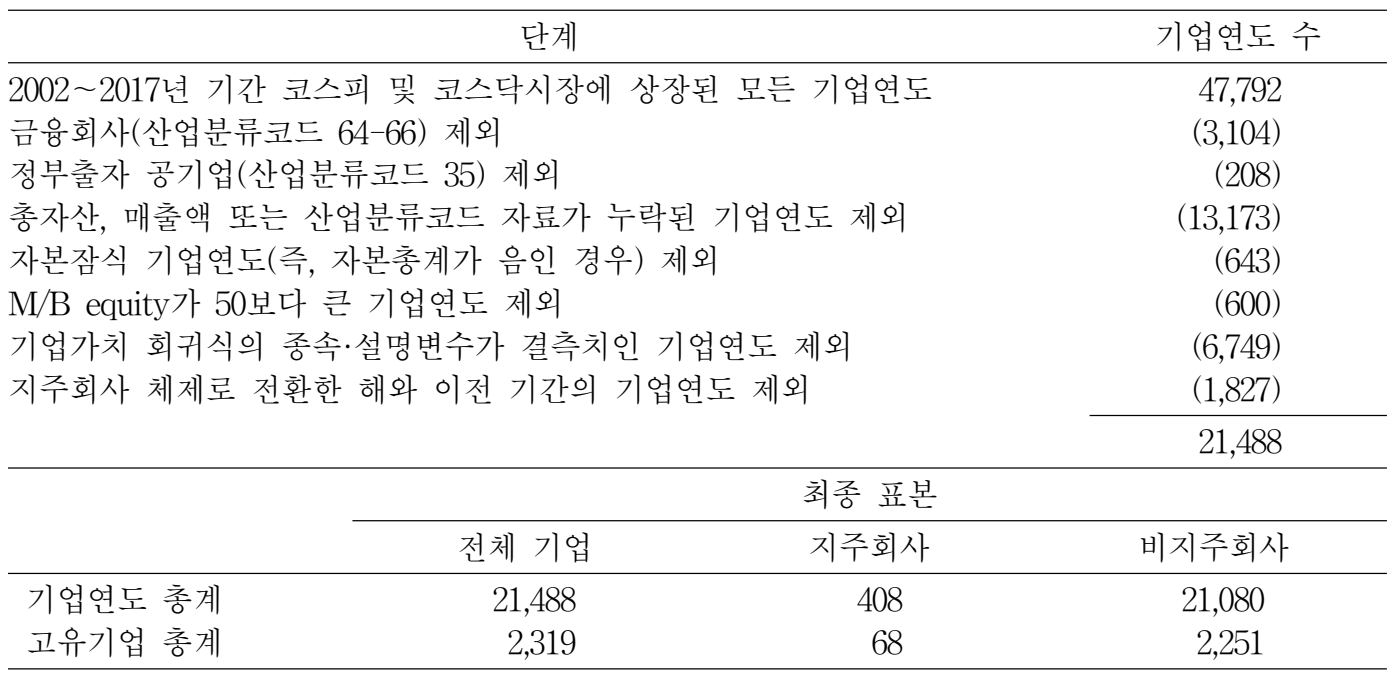

패널 $\mathrm{B}$ : 표본의 연도별 분포

\begin{tabular}{cccc}
\hline & 전체 기업 & 지주회사 & 비지주회사 \\
\hline 2002년 & 881 & 1 & 880 \\
2003년 & 1,042 & 3 & 1,039 \\
2004년 & 1,074 & 4 & 1,070 \\
2005년 & 1,106 & 4 & 1,102 \\
2006년 & 1,152 & 4 & 1,148 \\
2007년 & 1,210 & 8 & 1,202 \\
2008년 & 1,306 & 14 & 1,292 \\
2009년 & 1,426 & 22 & 1,404 \\
2010년 & 1,429 & 25 & 1,404 \\
2011년 & 1,446 & 29 & 1,417 \\
2012년 & 1,451 & 32 & 1,419 \\
2013년 & 1,421 & 41 & 1,380 \\
2014년 & 1,443 & 45 & 1,398 \\
2015년 & 1,591 & 52 & 1,539 \\
2016년 & 1,708 & 58 & 1,650 \\
2017년 & 1,802 & 66 & 1,736 \\
\hline 합계 & 21,488 & 408 & 21,080 \\
\hline
\end{tabular}


The Holding Company Discount in Korea's Stock Market

\section{〈부록 1〉연구 표본(계속)}

패널 C: 지주회사의 산업별 분포

\begin{tabular}{clc}
\hline 산업분류코드(KSIC2) & \multicolumn{1}{c}{ 산업 } & 기업연도 수 \\
\hline 21 & 의료용 물질 및 의약품 제조업 & 1 \\
26 & 전자 부품, 컴퓨터, 영상, 음향 및 통신장비 제조업 & 3 \\
28 & 전기장비 제조업 & 4 \\
30 & 자동차 및 트레일러 제조업 & 4 \\
32 & 가구 제조업 & 5 \\
71 & 전문 서비스업 & 383 \\
73 & 기타 전문, 과학 및 기술 서비스업 & 8 \\
\hline
\end{tabular}

패널 D: 지주회사 체제를 취하고 있는 기업집단 내 기업의 수

\begin{tabular}{lcc}
\hline & 기업연도 & 고유기업 \\
\hline 지주회사 & 408 & 68 \\
자회사 & 925 & 154 \\
손자회사 & 163 & 27 \\
\hline 합계 & 1,496 & 249 \\
\hline
\end{tabular}

패널 $\mathrm{E}$ : 사실상 지주회사 리스트(기업연도 264개; 고유기업 18개)

두산, 한화, 동국제강, 금호산업, 신세계, 효성, 포스코, 태영건설, 현대중공업, OCI, S-Oil, 금호석유, $\mathrm{KT}, \mathrm{KT} \& \mathrm{G}$, 네이버, 대우조선해양, 대우건설, 이마트 
한국증권학회지 제48권 6호 (2019)

〈부록 2〉 변수 정의

괄호 안의 숫자는 FnGuide의 코드번호이다. Eqt. Stake/Assets와 Div. Income/Sales는 별도(또는 개별재무제표)를 이용해 작성하였으며 이외의 모든 재무제표 변수는 연결재무제표를 사용하거나 연결재무 제표가 없는 기업의 경우는 개별재무제표를 사용하였다.

기업가치 회귀식의 변수 정의

\begin{tabular}{|c|c|}
\hline $\mathrm{M} / \mathrm{B}$ equity & $\begin{array}{l}\text { (보통주 주가 }(\mathrm{S} 430003700) \times \text { 보통주 상장주식수(S430001300))/ } \\
\text { (자기자본(4001190380)-우선주 자본금 }(4001130090) \text { ) }\end{array}$ \\
\hline Holding Dummy & 공정거래법상 지주회사는 1 , 그 이외의 회사는 0 을 부여하는 더미변수 \\
\hline Eqt. Stake/Assets & 계열사지분자산(1001111660)/총자산(1001190010) \\
\hline Div. Income/Sales & 배당수익(1001290760)/매출액(1001210000) \\
\hline $\log$ (Assets) & 총자산(4001190010)의 자연로그 \\
\hline$\Delta \mathrm{PPE} / \mathrm{lag}$ Sales & $\begin{array}{l}\text { (유형자산(4001190030)-전년도 유형자산(4001190030))/ } \\
\text { 전년도 매출액(4001210000) }\end{array}$ \\
\hline EBIT/Sales & 영업이익(4001211430)/매출액(4001210000) \\
\hline Leverage & $\begin{array}{l}\text { (단기부채+장기부채)/총자산(4001190010), 단기부채=단기사채(4001181470) } \\
\text { +단기차입금(4001121700)+유동성 장기부채(4001190620) } \\
\text { +유동금융부채(4001190630), 장기부채=사채(4001190460) } \\
\text { +장기차입금(4001190470)+비유동금융부채(4001190480) }\end{array}$ \\
\hline Volatility & 연간 일별 주가수익률(S41000170F)의 표준편차 $\times \sqrt{252}$ \\
\hline
\end{tabular}

Campello and Graham(2013) 회귀식의 변수 정의

\begin{tabular}{|c|c|}
\hline $\mathrm{M} / \mathrm{B}$ equity & 상동 \\
\hline $\mathrm{ROA}$ & 영업이익(4001211430)/총자산(4001210000) \\
\hline CAPEX & 현금흐름표상 투자금액(4001390270)/전년도 총자산(400121000) \\
\hline$\Delta$ Sales & $\begin{array}{l}\text { (매출액(4001210000)-전년도 매출액(4001210000))/ } \\
\text { 전년도 매출액(4001210000) }\end{array}$ \\
\hline Liquid Assets & 유동자산(4001190240)/총자산(4001210000) \\
\hline Leverage & 상동 \\
\hline $\log ($ Assets $)$ & 상동 \\
\hline$\Delta$ Ind. Sales & 해당 산업(KSIC2 기준) 매출액(4001210000) 1년 성장률 \\
\hline$\Delta$ Ind. CAPEX & 해당 산업(KSIC2 기준) 투자금액(4001390270) 1년 성장률 \\
\hline$\Delta$ Ind. R\&D & 해당 산업(KSIC2 기준) 연구개발비(CP30700001) 1년 성장률 \\
\hline \multicolumn{2}{|c|}{ 투자관심도 변수 정의 } \\
\hline 거래회전율(I) & 일별(주식거래량(S41000080F)/상장주식수(S41000100F))의 연평균 \\
\hline 거래회전율(II) & $\begin{array}{l}\text { 해당연도 일별 주식거래량(S41000080F)의 합계/(상장주식수(S41000100F)의 } \\
\text { 연평균) }\end{array}$ \\
\hline
\end{tabular}


The Holding Company Discount in Korea's Stock Market

〈부록 3〉 펀더멘탈 기업가치 회귀식 추정 결과

Campello and Graham(2013)의 방법론을 사용하여 펀더멘탈 $\mathrm{M} / \mathrm{B}$ equity를 추정한 회귀분석 결과이다. 표본기간은 2002 2017년이며 표본기업 전체(즉, 지주회사와 비지주회사를 합친 표본)에 대해 회귀식을 추정하였다. 변수의 정의는 <부록 $2>$ 에 제시되었다. 괄호 안의 수치는 firm-clustered standard errors를 사용한 $\mathrm{t}$ 값이며 ${ }^{*},{ }^{* *},{ }^{* * *}$ 는 각각 $10 \%, 5 \%, 1 \%$ 수준의 양측검정 유의성을 의미한다.

\begin{tabular}{|c|c|}
\hline & 종속변수: M/B equity \\
\hline $\mathrm{ROA}(\mathrm{t}-1)$ & $-9.143(-11.71)^{* * * *}$ \\
\hline $\mathrm{ROA}(\mathrm{t}-2)$ & $-3.311(-4.45)^{* * *}$ \\
\hline CAPEX $(t-1)$ & $0.008(2.32)^{* *}$ \\
\hline CAPEX (t-2) & $0.007(2.23)^{* *}$ \\
\hline$\Delta$ Sales $(\mathrm{t}-1)$ & $0.565(4.22)^{* * *}$ \\
\hline$\Delta$ Sales $(t-2)$ & $0.570(6.63)^{* * *}$ \\
\hline Liquid assets $(\mathrm{t}-1)$ & $0.922(1.85)^{*}$ \\
\hline Liquid assets (t-2) & $0.486(0.94)$ \\
\hline Leverage $(t-1)$ & $1.683(3.19)^{* * *}$ \\
\hline Leverage $(t-2)$ & $1.053(2.24)^{* *}$ \\
\hline $\log ($ Assets $)(t-1)$ & $0.105(0.50)$ \\
\hline $\log ($ Assets $)(t-2)$ & $-0.443(-2.12)^{* *}$ \\
\hline$\Delta$ Ind. Sales $(t-1)$ & $0.074(1.67)^{*}$ \\
\hline$\Delta$ Ind. Sales $(t-2)$ & $0.120(2.41)^{* *}$ \\
\hline$\triangle$ Ind. CAPEX $(\mathrm{t}-1)$ & $0.019(2.06)^{* *}$ \\
\hline$\triangle$ Ind. CAPEX $(\mathrm{t}-2)$ & $0.014(1.67)^{*}$ \\
\hline$\Delta$ Ind. R\&D (t-1) & $0.000(-0.01)$ \\
\hline$\Delta$ Ind. R\&D (t-2) & $0.003(0.20)$ \\
\hline Intercept & $9.361(7.12)^{* * *}$ \\
\hline 연도고정효과 & Yes \\
\hline 관측치 수 & 21,488 \\
\hline Adj. $R^{2}$ & 0.102 \\
\hline
\end{tabular}

